\title{
High-magnitude flooding across Britain since AD 1750
}

\author{
Neil Macdonald and Heather Sangster \\ Department of Geography and Planning, University of Liverpool, Liverpool, L69 7ZT, UK \\ Correspondence to: Neil Macdonald (neil.macdonald@liverpool.ac.uk)
}

Received: 23 July 2014 - Discussion started: 8 September 2014

Revised: 27 January 2017 - Accepted: 13 February 2017 - Published: 20 March 2017

\begin{abstract}
The last decade has witnessed severe flooding across much of the globe, but have these floods really been exceptional? Globally, relatively few instrumental river flow series extend beyond 50 years, with short records presenting significant challenges in determining flood risk from highmagnitude floods. A perceived increase in extreme floods in recent years has decreased public confidence in conventional flood risk estimates; the results affect society (insurance costs), individuals (personal vulnerability) and companies (e.g. water resource managers). Here, we show how historical records from Britain have improved understanding of high-magnitude floods, by examining past spatial and temporal variability. The findings identify that whilst recent floods are notable, several comparable periods of increased flooding are identifiable historically, with periods of greater frequency (flood-rich periods). Statistically significant relationships between the British flood index, the Atlantic Meridional Oscillation and the North Atlantic Oscillation Index are identified. The use of historical records identifies that the largest floods often transcend single catchments affecting regions and that the current flood-rich period is not unprecedented.
\end{abstract}

\section{Introduction}

One of the greatest challenges presently facing river basin managers is the dearth of reliable long-term data on the frequency and severity of extreme floods, with an average gauged record length of $\sim 40$ years in the UK (Marsh and Lees, 2003). Historical accounts represent a precious resource when considering the frequency and risks associated with high-magnitude low-frequency floods (Williams and Archer, 2002). Historical flood records are found in a variety of forms, directly or indirectly chronicling historic floods (Brázdil et al., 2005); sources include documentary accounts, e.g. journals, newspapers and diaries (McEwen, 1987; Brázdil et al., 2006, 2012), flood stones (markers indicating the greatest spatial flood extent) and epigraphic markings (inscribed water levels on structures; see Macdonald, 2007) for sites around the globe (Popper, 1951; Camuffo and Enzi, 1996; Brázdil, 1998; Demarée, 2006; Bürger et al., 2007). Historical accounts often contain important details including incidence, magnitude, frequency (comparable to other historic events) and seasonality. Historic centres often retain the most complete series of historical records, as the presence of literate individuals associated with important monastic, trade and/or governmental functions provide detailed flood accounts (Macdonald et al., 2006), an important aspect in the preservation of early materials. This paper presents the first coherent large-scale national analysis undertaken on historical flood chronologies in Britain, providing an unparalleled network of sites (Fig. 1), permitting analysis of the spatial and temporal distribution of high-magnitude flood patterns and the potential mechanisms driving periods of increased flooding at a national scale (Britain) since $\mathrm{AD}$ 1750.

\section{Series construction}

Site inclusion within this study is dependent on the availability of detailed historical accounts and the presence of relatively long instrumental river flow/level series ( $>40$ years in length). Historical accounts were collated and augmented onto existing instrumental series, with historical flood levels estimated based on documented descriptions (see Wetter et al., 2011), physical evidence or epigraphic markings, providing estimates of flow (Herget and Meurs, 2010), with greater significance placed on ranking event severity than on precise discharge estimation (Payrastre et al., 2011) (Fig. 2). Only those floods (historical and instrumental) exceeding the 


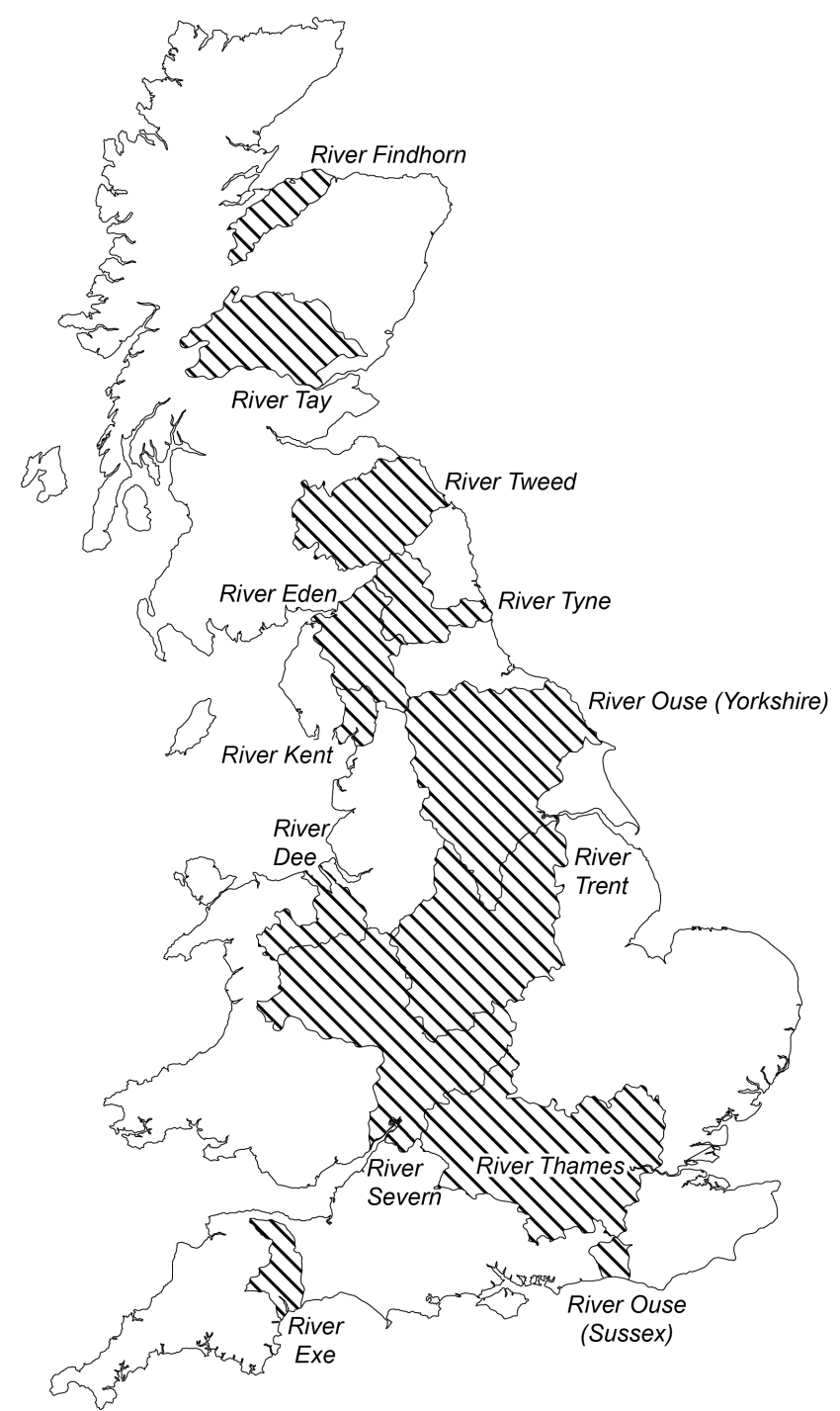

Figure 1. Catchments for which historical flood reconstruction has been undertaken, county names are added in parentheses where multiple catchments exhibit the same name.

90th percentile based on the instrumental period are included (Fig. 2), thus ensuring only the largest events are considered, which provides a threshold of events comparable to those likely to have been recorded throughout the historical period. The largest flood events are also unlikely to be significantly impacted by moderate anthropogenic-driven changes within catchments (Mudelsee et al., 2003; Macdonald and Black, 2010; Hall et al., 2015); where significant catchment/channel and floodplain (see Lewin, 2010) changes have occurred (channel cross section, land use, urbanisation, etc.), the impact, where possible, has been accounted for using available information (Elleder et al., 2013), with greater confidence in comparable catchment form from ca. AD 1750, compared to earlier periods (Macdonald et al., 2014). The data used within this paper focus on single locations, as merging of histori- cal data over whole catchments is fraught with difficulties (Böhm et al., 2015); furthermore, "stable" sections of channel are selected, where possible, at sites with long detailed historical flood records.

\section{Catchment characteristics}

A brief summary of the catchment conditions and anthropogenic influence on each of the systems is provided below; detailed in depth discussions of local histories and land use practices are provided in the cited papers.

\subsection{River Findhorn, Forres}

The River Findhorn drains the Monadhliath Mountains in central Scotland, with a predominantly metamorphic bedrock including granitic intrusions, extensive blanket peat coverage with agricultural activities along the coastal strip and much heath and mountainous land, with limited anthropogenic development within the catchment. Instrumental series are available at Shenachie $(07001 ; 1960)$ and Forres $(07002$; 1958), with an upstream catchment area of $782 \mathrm{~km}^{2}$; the Findhorn has received considerable attention within a British context (NERC, 1975; Newson, 1975; Acreman, 1989) as it includes one of the best documented "extreme" floods of the nineteenth century. An account of the great floods of August 1829, in the province of Moray and adjoining districts by Sir Thomas Dick Lauder (1830) provides a detailed eyewitness account of the floods and the destruction across the region, with detailed information permitting the reconstruction of the flood. Throughout Lauder's account he frequently comments on human modification of the landscape, partly attributing the severity of the 1829 flood to agricultural improvement and drainage undertaken within the catchment in the decades of the late eighteenth and early nineteenth centuries. Within the instrumental period, the flood of 1970 is the largest, estimated at $2402 \mathrm{~m}^{3} \mathrm{~s}^{-1}$, but subsequently reduced to $1113 \mathrm{~m}^{3} \mathrm{~s}^{-1}$ following considerable reanalysis, with the 1829 flood estimated to be between 1500 and $1800 \mathrm{~m}^{3} \mathrm{~s}^{-1}$ (McEwen and Werritty, 2007). The present river channel consists of a number of bedrock sections, particularly within the upper catchment, with alluvial highly mobile sections within the lower catchment susceptible to lateral avulsion, though McEwen and Werritty (2007) note limited migration in most channel sections since the present channel was excavated during the 1829 flood. There are no severe flood events recorded on the Findhorn between the flood of 1829 and the start of the instrumental series in the 1950s, from which reliable estimates can be derived; however, it is notable that several floods are described in the period between 1914 and 1924, though accurate estimates of their discharge are not achievable from the available records. 


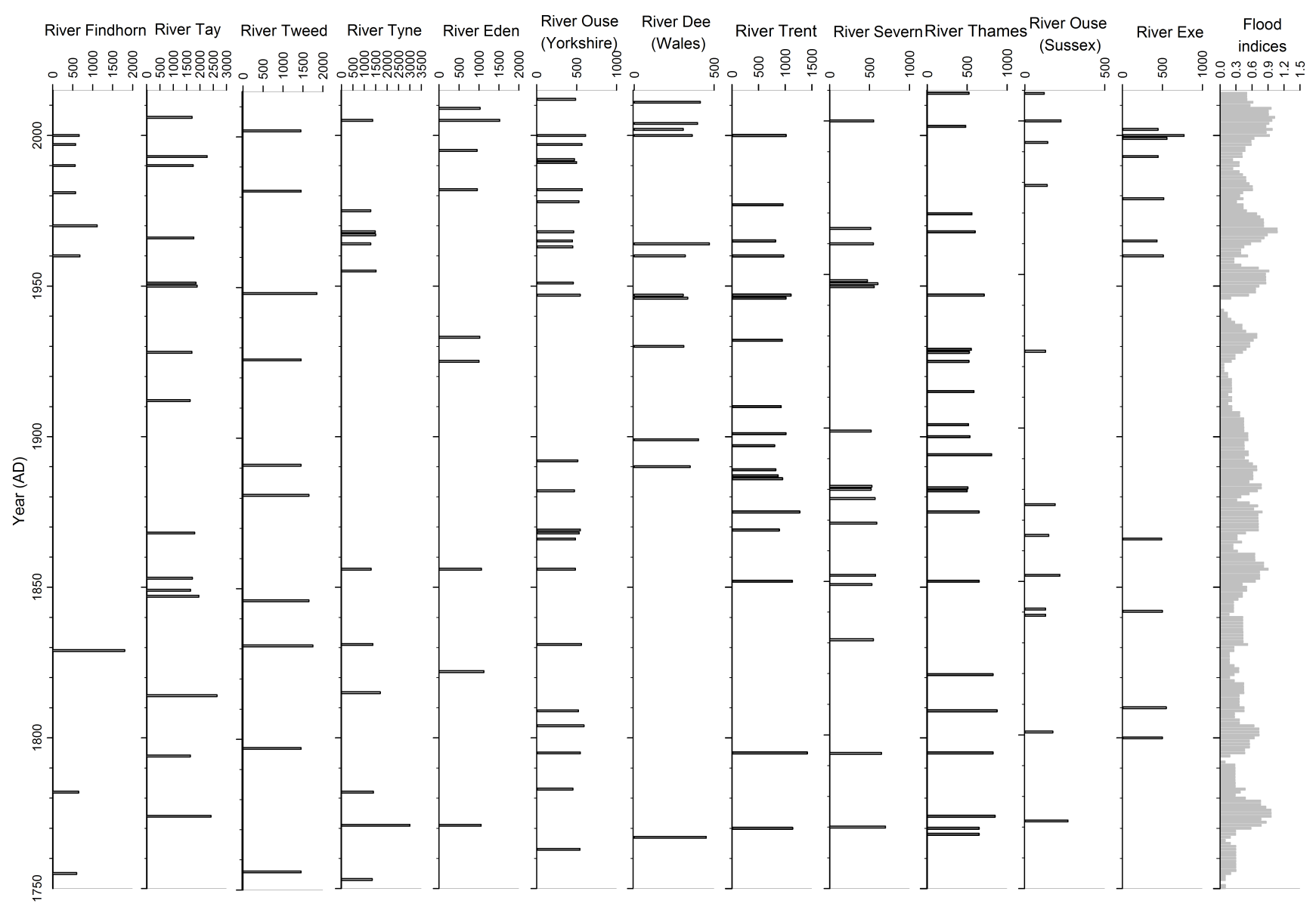

Figure 2. Historical flood chronologies for sites across Britain, showing events that exceed the 0.9 percentile (based on the instrumental record; river discharges are given as $\mathrm{m}^{3} \mathrm{~s}^{-1}$ ). River chronologies (left-right) Findhorn, Tay, Tweed, Tyne, Eden, Ouse (Yorkshire), Dee (Wales), Trent, Severn, Thames, Ouse (Sussex), Exe, and flood indices 1750-2014.

\subsection{River Tay, Perth}

The River Tay has the largest mean discharge of any British river $\left(165 \mathrm{~m}^{3} \mathrm{~s}^{-1}\right.$; Marsh and Lees, 2003) with a mean annual flood of $990 \mathrm{~m}^{3} \mathrm{~s}^{-1}$. Although relatively small by European standards, the Tay catchment is one of Britain's largest, draining $4690 \mathrm{~km}^{2}$ of the Scottish Highlands, with several mountain peaks $>1000 \mathrm{~m}$ AOD (metres above ordnance datum). Annual precipitation in excess of $3000 \mathrm{~mm} \mathrm{a}^{-1}$ in the western Highlands is not uncommon as a result of its high elevation and westerly location (Roy, 1997); by contrast lowland sections of the catchment (around Perth) have an average annual rainfall of $\sim 700 \mathrm{~mm} \mathrm{a}^{-1}$ (Jones et al., 1997) and annual evapotranspiration losses of $\sim 450 \mathrm{~mm} \mathrm{a}^{-1}$ (Harrison, 1997). The River Tay has six major tributaries: the Almond, Earn, Garry, Isla, Lyon and Tummel, with a tidal limit near the Tay-Almond confluence approximately $4 \mathrm{~km}$ upstream of Perth. The longest gauged flow record is at Caputh (15003; since 1947); despite being shorter, the Ballathie (15006) record (1952) includes flows from the River Isla tributary, $\sim 6 \mathrm{~km}$ upstream of the city of Perth, and therefore pro- vides a better comparison to epigraphic flood levels in the city, most notably those on Smeaton's Bridge (Macdonald et al., 2006). Generally, the catchment is characterised by thin soils and impermeable bedrock with high runoff rates, while Lochs Tummel, Tay and Lyon significantly reduce flooding by attenuating flood peaks. The development of major hydroschemes in the Tay catchment completed in 1957 (Payne, 1988), incorporates $42.2 \%$ of the upper Tay catchment area (Marsh and Lees, 2003). The development consists of two power schemes, (i) the Tummel-Garry scheme $\left(1649 \mathrm{~km}^{2}\right)$ to Pitlochry Dam (including inflows from a further $130 \mathrm{~km}^{2}$ of the headwaters of the River Spey; Marsh and Lees, 2003), and (ii) to the south, the Breadalbane scheme which controls a further $511 \mathrm{~km}^{2}$ draining to Comrie Bridge at the TayLyon confluence. Four sets of flood information are used at Perth for constructing the flood series: (i) a gauged record since 1952 at Ballathie; (ii) epigraphic makings on Smeaton's Bridge in central Perth (intermittent since 1814); (iii) a series of river-level readings from the old waterworks in Perth (intermittent since 1877); and episodic documentary accounts, which extend back to AD 1210 (Macdonald et al., 2006), 
though only those after AD 1750 are included within this study. A rating curve constructed from peak flows at the Ballathie gauging station and sites in Perth enables estimated discharges to be assigned to historic flood flows (Macdonald et al., 2006). The rich documentary sources reporting floods in Perth are compared to contemporary events within the augmented series with reference to relative extent in relation to buildings or road junctions. For the purpose of this analysis, it is assumed that the relationship between stage and discharge at the site of Smeaton's Bridge and Ballathie has not changed over the intervening period; see Macdonald et al. (2006) and Werritty et al. (2006) for a more detailed discussion of the flood history and flood series reconstruction, hydrological changes and landscape change within the catchment.

\subsection{River Tweed}

The River Tweed rises at Tweed's Well in the Lowther Hills flowing east through the Scottish Boarders before entering Northumberland in northeastern England and flowing into the North Sea at Berwick-on-Tweed. The River Tweed consists of two principal rivers, the Tweed and Teviot draining from the west and southwest respectively, and the Whiteadder draining from the northwest entering the Tweed ca. $3 \mathrm{~km}$ upstream of Berwick. The reservoirs in the headwaters have a limited impact on the river discharges downstream, with $\sim 30 \%$ lowland agriculture and $\sim 70 \%$ upland given to moorland and upland hill pastures (Marsh and Hannaford, 2008), with few urban centres, the exceptions being the towns of Berwick-upon-Tweed, Coldstream and Kelso. The geology is of mixed bedrock, predominantly impervious Palaeozoic formations with thick superficial deposits. Annual precipitation is ca. $790 \mathrm{~mm} \mathrm{a}^{-1}$ (Marchmount House) (McEwen, 1989).

There is a long well-documented flood history for the town of Kelso, a historic strategically important town on the England-Scottish boarder, which was held by both countries several times during various conflicts. The town was important commercially as a market town, with a number of historic monastic centres nearby (e.g. Lindisfarne and Kelso Monastery), with the town located on one of the main routes between London and Edinburgh for much of the period. The town of Berwick on the coast contained the oldest bridging points on the Tweed, with the earliest recorded flood dating from 1199 resulting in the loss of the bridge and subsequent rebuilding costs; the second bridge was destroyed by the English in 1216, with the third lost in 1294 destroyed again by flooding (ICE, unpublished data). The first bridge at Kelso was built in 1754 and replaced a ferry, but in October 1756 part of the bridge collapsed during a flood killing six; the bridge was repaired but a storm in October 1797 lead to its collapse, with a replacement bridge constructed in AD 1803 by the engineer John Rennie.
A gauged river flow series for Sprouston (21021) and Norham (21009) exists from 1969 to present and 1959 to present respectively, with Sprouston located $\sim 1 \mathrm{~km}$ downstream of Kelso and Norham located $\sim 9 \mathrm{~km}$ upstream of the Whiteadder confluence draining from the north $(\sim 12 \mathrm{~km}$ upstream of the coastal town of Berwick-upon-Tweed). Historical flood series have been produced by McEwen (1990) for the rivers Tweed, Teviot, Whiteadder and Leader (Tweed tributary) from 1750, with a longer series for the Tweed starting in $\mathrm{AD} 218$, but early records are of questionable reliability as the original sources are often unknown. The long chronology produced by McEwen (1990) notes several flood events prior to AD 1750, with major floods since at Kelso in ranked order (1) 1948, (2) 1831, (3) 1846 and 1881, (4) 1891,1926 and $1982\left(1452 \mathrm{~m}^{3} \mathrm{~s}^{-1}\right)$, (5) 1956, 1962 $\left(1174 \mathrm{~m}^{3} \mathrm{~s}^{-1}\right.$, Norham) and $1977\left(1269 \mathrm{~m}^{3} \mathrm{~s}^{-1}\right)$; discharge at Sprouston unless stated. Flood events since the publication of the study by McEwen (1990) of a comparable magnitude $\left(>1250 \mathrm{~m}^{3} \mathrm{~s}^{-1}\right)$ occurred in $2002\left(1444 \mathrm{~m}^{3} \mathrm{~s}^{-1}\right)$ and $2005\left(1436 \mathrm{~m}^{3} \mathrm{~s}^{-1}\right)$, which appear to have a comparable discharge to that of 1982 and therefore are placed in the rank four category. Additional floods not identified by McEwen occurred in 22 October 1756 and 26 October 1797, both of which led to the loss of the bridge, the former resulting in several fatalities (Star, 1797). Based on the descriptive accounts and details provided in McEwen (1990) and other sources, discharges for the historic events are presented as $1850 \mathrm{~m}^{3} \mathrm{~s}^{-1}$ for 1948 (rank 1), $1750 \mathrm{~m}^{3} \mathrm{~s}^{-1}$ for 1831 (rank 2), $1650 \mathrm{~m}^{3} \mathrm{~s}^{-1}$ for 1846 and 1881 (rank 3), $1450 \mathrm{~m}^{3} \mathrm{~s}^{-1}$ for 1891 and 1926 (rank 4) and $1250 \mathrm{~m}^{3} \mathrm{~s}^{-1}$ for 1956 (rank 5). For the floods of 1756 and 1797, an estimated discharge of $1450 \mathrm{~m}^{3} \mathrm{~s}^{-1}$ is used within the analysis; each event was worthy of description, with several attributed to the loss of bridges, life or other notable structures and therefore are likely to be of equivalent or greater than rank 4.

\subsection{River Tyne}

The River Tyne in northeastern England consists of two principal rivers, the southern and northern Tyne rivers, which join near the town of Hexham to form the River Tyne. The geology of the upper catchment is characterised by Carboniferous Limestone and Millstone Grit, with a thick layer of alluvial drift material covering the lower catchment, with land use being predominantly upland farming, grassland and woodland with relatively little urban development. The northern Tyne rises near the Scottish boarder before flowing southeast; the principal water body on the tributary is Kielder Water. The construction of Kielder Water, the largest UK reservoir with the potential to hold 200 billion litres, has considerably altered flood discharges within the northern Tyne since its completion in 1982, attenuating $\sim 240 \mathrm{~km}^{2}(11 \%)$ of the catchment. Archer et al. (2007) identified that the impact on flood discharges ranges from $114 \mathrm{~m}^{3} \mathrm{~s}^{-1}$ at mean an- 
nual flood to $225 \mathrm{~m}^{3} \mathrm{~s}^{-1}$ at the 20 -year return period, and is liable to increase with fewer frequent events. The southern Tyne's source is on Alston Moor in Cumbria, before flowing north-northeast through the Tyne Gap (there are no notable impoundment structures on the river) before reaching its confluence with the northern Tyne near Hexham.

The River Tyne $\left(\sim 321 \mathrm{~km}\right.$ length and $3296 \mathrm{~km}^{2}$ catchment) has undergone extensive river channel modification over recent centuries as a result of gravel extraction (Rumsby and Macklin, 1994), with Archer (1993) estimating approximately 4.5 million tons having been extracted during the period 1890-1970, from 15 sites along the rivers course. The level of gravel extraction has had a considerable impact on the channel and bedform of the river within the lower reaches, altering the stage-discharge relationships; therefore, the creation of a reliable long flood series is challenging. Extensive analysis of available historical information was undertaken by Archer (1992) for his book Land of Singing Waters, and subsequent book Tyne and Tide (Archer, 2003). The discharge series for the gauging station at Bywell (1956) is used, but earlier flows are modified after Archer et al. (2007) to account for gravel extraction (1955-1961) and the construction of Kielder Water. The gauge at Bywell was installed following severe flooding in January 1955, with an estimated discharge of $1520 \mathrm{~m}^{3} \mathrm{~s}^{-1}$ (D. Archer, personal communication, 2005). Notable historical flood discharges on the Tyne have previously been estimated, particularly the 1815 $\left(1700 \mathrm{~m}^{3} \mathrm{~s}^{-1}\right)$ and $1771\left(3900 \mathrm{~m}^{3} \mathrm{~s}^{-1}\right)$ floods, with an uncertainty of ca. $20 \%$ (Archer, 1993), the latter being the most devastating flood event recorded, not only on the Tyne but also regionally, with many rivers losing bridges during this event (e.g. see Archer, 1987). The 1771 flood appears to be the largest recorded, with 1815 ranked third, with the flood of 1339 ranked second. The information available for the flood of 1339, is limited, though the Chronicle of Lanercost, 1272-1346 (translated by Sir Maxwell, 1913) describes the event as

... on the third day before the feast of the Assumption of the Glorious Virgin [14th August] a marvellous flood came down by night upon Newcastle-on-Tyne, which broke down the townwall at Walkenow for a distance of six perches, where 160 men, with seven priests and others, were drowned.

Jervoise (1931) noted that a stone bridge built at Newcastle by the Newcastle Corporation and the Bishop of Durham in AD 1248 survived a flood when 90-years old (ca. 1339), but suffered severe flood damage with the loss of 120 lives and was eventually destroyed during the 1771 flood. The severity of the floods of 1771 and 1815 led to the production of a book An account of the great floods in the rivers Tyne, Tees, Wear, Eden, ca. in 1771 and 1815 in 1818 by William Garret, documenting the impacts of the floods across northern England. A number of additional accounts document floods between 1763 and the start of the gauged series in 1956, these include 1763, 1782, 1831, 1856, 1881 and 1903; within this study these are estimated to have discharges between 1225 and $1375 \mathrm{~m}^{3} \mathrm{~s}^{-1}$, making them broadly comparable to the 2005 flood $\left(1370 \mathrm{~m}^{3} \mathrm{~s}^{-1}\right)$ on the River Tyne. As Archer et al. (2007) noted when commenting on the 1955 and 2005 floods, it is conceivable that the floods of 1763,1782 , 1831 and 1856 may have been greater, as the estimation of historical discharges on the River Tyne are particularly challenging as a result of the uncertainties in estimation. The recent December 2015 flood on the Tyne is likely to be greatest since 1771, with a level exceeding the 1815 event by $0.4 \mathrm{~m}$, but below that of 1771, with a provisional discharge of approximately $1700 \mathrm{~m}^{3} \mathrm{~s}^{-1}$ (Parry et al., 2016).

\subsection{River Eden}

The River Eden in northwestern England, has a catchment area of ca. $2300 \mathrm{~km}^{2}$, it flows in a north-northwest direction for much of its course from its source at Black Fell Moss, Mallerstang, in the Yorskhire Dales through to the Solway Firth. It has four principal tributaries, the Eamont, Irthing, Petteril and Caldew. The Earmont drains the upland area of the eastern Lake District with a confluence with the Eden near Penrith, followed by the Irthing tributary joining from the east-northeast ca. $10 \mathrm{~km}$ upstream of Carlisle, with the River Petteril confluence ca. $1 \mathrm{~km}$ upstream and the Caldew confluence adjacent to the city of Carlisle. The catchments geology consists of Carboniferous Limestones to the east and impervious Lower Palaeozoic of the Lake District massif to the west, with extensive Permo-Triassic sandstone within the Vale of Eden (Marsh and Hannaford, 2008). The land use is predominantly rural, with moorland and upland grazing at elevation and grasslands at lower elevations and limited urban coverage except for the towns of Appleby, Penrith and the city of Carlisle. Precipitation can exceed $2000 \mathrm{~mm} \mathrm{a}^{-1}$ at elevation in the Lake District, with an average precipitation at Carlisle of $787 \mathrm{~mm} \mathrm{a}^{-1}$ (Todd et al., 2015).

Severe flood events have affected Carlisle in recent years $(2015,2005)$, with three people killed and $\sim 2700$ properties affected in 2005. A rich detailed history of flooding exists for Carlisle, with a combination of existing reconstructions (Smith and Tobin, 1979; Macdonald 2006; Patterson and Lane, 2012), a series of flood marks on Eden Bridge since 1822 and descriptive accounts from multiple sources augment the instrumental series from Sheepmount gauging station $(76007 ; 1967)$; a gauged series is also available from Warwick bridge from 1959, but this is upstream of the confluence with the Irthing. The $2005\left(1516 \mathrm{~m}^{3} \mathrm{~s}^{-1}\right)$ flood event is recorded by the Environment Agency as $1 \mathrm{~m}$ higher than the previous highest mark of 1822 , with the flood of $2015\left(1680 \mathrm{~m}^{3} \mathrm{~s}^{-1}\right) 0.6 \mathrm{~m}$ higher than 2005 (Environment Agency, 2016); the recent flood of December 2015 is provisionally estimated at approximately $1700 \mathrm{~m}^{3} \mathrm{~s}^{-1}$ (Parry et al., 2016). Following the severe floods of 1968 , Smith and 
Tobin (1979) mapped the flood extent of all known flood events between 1800 and 1968, producing a ranked series of 49 major floods at Carlisle, of which 1822, 1856, 1925 and 1968 are the largest; these are all also marked on Eden Bridge. The flood of 1771, whilst notable does not appear as extreme as witnessed in catchments on the eastern side of northern England, accounts of bridges being lost over several of the principal tributaries are documented in Garret (1818), with livestock lost at Hole Farm near Carlisle. Notable floods prior to 1771 include 1763 and 1767 (Chronology of British Hydrological Events, Black and Law, 2004); the snowmelt flood of 1767 is documented in the weather accounts of the Bishop of Carlisle as discussed by Todd et al. (2015).

\subsection{River Ouse, York}

The Yorkshire Ouse located in northeastern England has a catchment area of $3315 \mathrm{~km}^{2}$ upstream of Skelton, the site of the present gauging station (27009), on the northern outskirts of the city of York. Upstream of the city the main tributaries of the River Ouse are the Rivers Swale, Ure and Nidd, together draining much of the northern Pennines. Precipitation totals vary throughout the catchment, ranging from in excess of $1800 \mathrm{~mm} \mathrm{a}^{-1}$ in upland areas to less than $600 \mathrm{~mm} \mathrm{a}^{-1}$ in the Vale of York and adjacent lowland regions (Meteorological Office, 2002). The geology of the upper catchment is characterised by Carboniferous Limestone and Millstone Grit, with a thick layer of alluvial drift material covering the lower catchment in the Vale of York. Land use varies throughout the catchment, with predominantly arable and pastoral farming in lowland areas (Dennis et al., 2003), with increasing levels of grassland, rough grazing, heathland and moorland at higher altitudes. The influence of drainage and particularly gripping in the Upper Pennines is unlikely to significantly influence flooding in the lower catchment, as relatively small changes within the headwaters are aggregated out by the time flood waters reach the lower catchment (Longfield and Macklin, 1999). The principal flood generating mechanisms within the catchment during the instrumental period (1960s-present) are persistent rainfall over a saturated catchment associated with westerly and cyclonic systems and combined rainfall-snowmelt events (Macdonald, 2012). The tidal limit of the Yorkshire Ouse is downstream of present-day York.

The historical flood record for the city of York is one of the most detailed in Britain (Macdonald and Black, 2010). The instrumental series is unique in that it provides the longest continuous annual maximum flow series in Britain, derived from river-level data obtained from adjacent stage boards (all within $\sim 200 \mathrm{~m}$ ) at Ouse Bridge (1877-1892), Guildhall (1893-1963) and the Viking Hotel (from 1963), producing an augmented stage series. These stage records were coupled with data from the gauging station at Skelton (27009; 1969) to produce a rating curve, allowing for a continuous series of annual maxima flows to be produced from 1877
(Macdonald and Black, 2010). Based on the analysis of historical documents, the channel cross section has remained stable throughout the city reach during the last 250 years, as the area is confined within a walled section with occasional landings (see Rocque's map of 1750). The city of York has three main bridges: the most recently constructed Skeldergate Bridge (1882) and Lendel Bridge (1863) are both new bridge sites, and the Ouse Bridge, which was reconstructed in 1821 and is the fifth bridge following Roman, Viking, medieval (destroyed during the flood of 1564) and sixteenth century bridges. The influence of the historical bridges at high flow is difficult to estimate as little information remains (other than an engraving of the fourth bridge of 1565-1810); whilst the impact of the contemporary bridges appears minimal, as during the floods of 2000, some localised backing-up of flow at Ouse Bridge was observed, with little impact on the overall water levels upstream and downstream. Analysis of epigraphic flood markings (inscribed markings; Macdonald, 2007) inside the basement of the old Merchant Venturers' Hall in central York illustrates how the city has built up over the original floodplain during the centuries. Although the ground level in York has been raised, analysis of historical maps and documentary accounts show little evidence of change in base river level during the historical period, though bathymetric surveys post large floods suggests that bed excavation of up to $2 \mathrm{~m}$ may occur at York, as seen post 1892 and 2000 floods (Macdonald, 2004). A detailed discussion of the flood history and flood series reconstruction is provided by Macdonald and Black (2010) and historical flood seasonality by Macdonald (2012).

\subsection{River Dee}

The River Dee's source is in Snowdonia on the eastern slope of Dduallt (the Black Hill); the river then flows down to Llyn Tegid (Lake Bala), a natural lake with an area of $1.6 \mathrm{~km}^{2}$, the largest natural water body in the Dee catchment, before flowing eastwards through a broad valley and the Vale of Llangollen, meandering northwards (Gurnell et al., 1994) through the Cheshire plain to its tidal limit at Chester Weir (NRA, 1993). Llyn Tegid has a long management history, with the level raised in the 1790s to support the Ellesmere Canal (constructed Thomas Telford) and subsequently for water resources, in the 1960s the original Telford sluices were bypassed and the lake level lowered, with new sluices constructed downstream at the confluence of the Afon (river) Tryweryn, this enabled $18 \mathrm{Mm}^{3}$ storage within Llyn Tegid, permitting up to $0.235 \mathrm{Mm}^{3}$ for daily abstraction and additional flood storage (NRA, 1993). In 1967 the construction of Llyn Celyn $\left(6.5 \mathrm{~km}^{2} ; 81 \mathrm{Mm}^{3}\right)$ was completed in the headwaters of the Afon Tryweryn, which can supply additional flood attenuation and hydropower and is operated in conjunction with the Bala Lake Scheme. In the 1900s and 1920s the Alwen reservoir was constructed $8 \mathrm{~km}$ downstream of Llyn Alwen to supply water to Birkenhead, near Liverpool, 
with subsequent inclusion into the Bala Lake Scheme in the 1960s; in 1979 Llyn Brenig $\left(3.7 \mathrm{~km}^{2}\right)$ was constructed and became part of the Dee regulation scheme with a capacity of $60 \mathrm{Mm}^{3}$; both Llyn Alwen and Brenig are located on the Afron Alewn tributary (NRA, 1993). The geology of the upper catchment is Lower Palaeozoic rocks with the lower catchment (below Llangollen) consisting of Carboniferous Limestones and sandstone outcrops. The land use of the upper Dee catchment is predominantly upland grazing and moorland, while the lowlands are grassland and mixed agriculture, with limited urban development, with the exception of Bala, Llangollen and Chester (Marsh and Hannaford, 2008).

The city of Chester has its origins in a settlement that developed around the Roman fort of Deva Victrix, quickly becoming an important port town. By the late seventh century Chester had become an important regional town; during the medieval period the town thrived, though the port by the fifteenth century had become silted, with the deepening of the channel in 1755 to allow for navigation. The Old Dee Bridge was built about 1387 (widened in 1826), following the loss of several wooden bridges from flooding $(1227,1280$, 1297 and 1353) and withstood the flood of 16 January 1551 (Stewart-Brown, 1933), with a Letters Patent granted to the citizens on 25 July 1387 by Richard II for the purpose of the construction of a bridge, following the destruction of a previous bridge. The earliest account of a bridge over the Dee comes from the Domesday Book (1086), which notes the bridge at Chester (Williams and Martin, 2003), though this likely follows earlier bridges and a Roman fording point. A sandstone weir was built in 1093 just upstream of site of the Old Dee Bridge for the Benedictine Abbey of St Werburgh's (now Chester Cathedral), to power a set of mills, which were demolished in 1910, with the weir converted to producing hydroelectric from 1913 to 1939 (Historic England, 2015); today the weir maintains its role as a tidal point preventing tidal transgression upstream. The rural and low population density for much of the catchment limits the likely recording of events, particularly in the earlier period, were the Welsh language and an oral tradition are prominent in weather recording in the uplands (Macdonald et al., 2010b); therefore, many of the records consulted focus on the lowland areas.

A river-level stage series has been available for Chester Weir (67020) since 1894, though the weir drowns at ca. $280 \mathrm{~m}^{3} \mathrm{~s}^{-1}$; a discharge series has been available for Chester Suspension Bridge since 1994, with a longer gauged series available from Manley Hall (1937-present) and Erbistock Rectory (1923-1970) with the pre-1970 series at Manley Hall calculated from the Erbistock series, but both sites are located ca. $50 \mathrm{~km}$ upstream of Chester, with notable flood attenuation in the lower Dee floodplain (Marsh and Hannaford, 2008), which accounts for an apparent reduction in discharge between Manley Hall and Chester Weir. The estimation of discharges at Chester is challenging as there has been considerable catchment management and change, with extensive regulation in the headwaters over the last ca. 200 years (Lambert, 1988). A series compiled for Chester Weir is presented, checked against the series for Manley Hall, with notable floods being those exceeding ca. $325 \mathrm{~m}^{3} \mathrm{~s}^{-1}$; during the instrumental series, events exceeding this threshold are 1899, 1946, 1964, 2000, 2004 and 2011. It is worth noting that the series at Chester Weir begins just after a severe flood in 1890, as British Rainfall reported (Symons, 1891, p. 5).

\subsection{River Trent, Nottingham}

The River Trent has five major tributaries: the Tame, Soar, Ryton, Derwent and Dove, draining a large section $\left(7486 \mathrm{~km}^{2}\right)$ of central England, with a mean annual discharge of $84.3 \mathrm{~m}^{3} \mathrm{~s}^{-1}$ at Colwick (28009), approximately $5 \mathrm{~km}$ downstream of the city of Nottingham (Marsh and Lees, 2003). Nottingham presents one of the longest and most detailed flood histories within Britain, with epigraphic markings indicating the level of the largest floods since 1852 inscribed into the abutment of Trent Bridge, an annual maxima series at Trent Bridge from 1884 until 1969, descriptive accounts since the thirteenth century and a gauged record from Colwick since 1958 (Macdonald, 2013). The wealth of records reflects the prominent role the city had as a trade and commercial centre, a site of strategic military importance historically and as an important bridging point. The catchment lies predominantly beneath the $250 \mathrm{~m}$ contour (Hains and Horton, 1969), with exceptions in the Peak District near the source of the rivers Derwent and Dove at over $450 \mathrm{~m}$ AOD (Edwards and Trotter, 1954). Bedrock varies throughout the catchment with the Peak District and higher altitudes predominantly Millstone Grit and Carboniferous Limestone with lowland areas covered by superficial alluvial deposits, beneath which are Red Sandstones and historically significant Coal Measures. Land use varies with rural hilly areas, forestry, pasture and rough grazing to the north, while arable farming dominates lowland areas. There are considerable population centres, namely Birmingham located on the River Tame in the upper catchment, Nottingham on the River Trent, Derby on the River Derwent and Leicester on the River Soar, providing a total urbanised coverage of around $11 \%$ (Marsh and Hannaford, 2008). Precipitation is largely determined by elevation, with northern sections of the catchment (Peak District) receiving $>1000 \mathrm{~mm} \mathrm{a}^{-1}$, reducing to $\sim 550 \mathrm{~mm} \mathrm{a}^{-1}$ in eastern areas, with an average of $\sim 750 \mathrm{~mm} \mathrm{a}^{-1}$ (Kings and Giles, 1997). The upper River Derwent flow is modified by three important impoundment structures, the Derwent (holding ca. $9.5 \mathrm{Mm}^{3}$ ), Howden (ca. $9 \mathrm{Mm}^{3}$ ) and Ladybower (ca. $28.5 \mathrm{Mm}^{3}$ ) reservoirs (Potter, unpublished data). Their role in reducing the magnitude of flood peaks in the lower catchment at Nottingham is minor, as the proportion of the catchment controlled by these reservoirs at Colwick is small $\sim 1.7 \%$ (IH, 1999). The present tidal limit of the Trent is Cromwell lock, $\sim 25 \mathrm{~km}$ downstream of Nottingham. 
The first map of Nottingham drawn by the notable cartographer John Speed in 1610 followed by subsequent maps in 1675 (Richard Hall), 1744 (Badder and Peat), 1835 (Sanderson) and 1844 (Drearden) detailed city development and changes to the areas adjacent to the River Trent, including channel improvements (e.g. construction of the Nottingham Canal running from the River Trent to the town centre in 1793). The canal construction and navigable depth of the Trent resulted in the development of an industrialised area adjacent to the river. The planform of the River Trent in the map of 1844 indicates stability within the channel, post ca. 1800 , with industrial development along the northern bank, in the area historically known as "the meadows" (Beckett, 1997). The River Trent has some of the oldest channel management in Britain (pre-Roman), with banking of several breaches in a series of sand dunes (Spalford Bank) between Girton in Nottinghamshire through to Marton Cliff, in Lincolnshire; these represent an important geomorphic structure, as when breached the floodwaters can travel into the Witham Valley, the city of Lincoln and subsequently into the Fens, causing substantial damage (e.g. the flood of 1795, see St James Chronicle, 1795). Floods breaking through the defences of the Spalford Bank can be used as indicative of flood magnitude, as breaching occurs at discharges of $\sim 1000 \mathrm{~m}^{3} \mathrm{~s}^{-1}$ (Brown et al., 2001). A detailed discussion of the flood history and flood series reconstruction is provided by Macdonald (2013).

\subsection{River Severn}

The River Severn is the longest river in the British Isles $(220 \mathrm{~km})$, and its source is on Plynlimon in the Cambrian Mountains of mid-Wales. The major tributaries are the Vyrnwy, Clywedog, Teme, Avon (Warwickshire) and Stour, with the River Wye draining into the Severn estuary. The upland areas in mid-Wales are predominantly given to upland grazing and moorland, with little urban development except for the towns of Newtown and Welshpool. The development of impoundment structures can have a notable impact on discharges, particularly at low flow, though these are more limited during high flow (Marsh and Hannaford, 2008); the most significant being Lake Vrynwy built in 1880 to supply water to the city of Liverpool $\left(\sim 60 \mathrm{Mm}^{3}\right)$ and Clywedog built in 1967, which supplies water to the city of Birmingham and can hold $0.05 \mathrm{Mm}^{3}$. The lower catchment is predominantly given to arable and cattle grazing, with large urban centres at Shrewsbury, Worcester and Gloucester. Whilst there has been an extensive history of land use and river modification, the implications on the largest flows appear limited as the impact is aggregated out, a view supported by Archer et al. (2007) when looking at the upper Severn catchment (Wales-England border).
The towns of Shrewsbury, Worcester, Tewkesbury and Gloucester all have a long history of flooding, with each representing historically important ports on the River Severn; in addition, the UNESCO world heritage site at Ironbridge Gorge (an early Industrial Revolution site) is located ca. $19 \mathrm{~km}$ downstream of Shrewsbury. These towns were important commercial, military and religious centres (Macdonald, 2006) and maintain important commercial roles through to the present, with each of the docks maintaining long waterlevel data series, the earliest from 1827 to present, which are currently being transcribed for further analysis. A number of bridges crossed the River Severn by the fourteenth century, including at Gloucester, Worcester and Bridgnorth (between Bewdley and Shrewsbury), with the earliest accounts indicating that a bridge was present at Worcester in the eleventh century. Unlike most major British river systems, there appears to have been few losses of bridges, with most damage to the early bridges arising from conflicts between the English and Welsh armies. For the purpose of this study, the site of Gloucester will not be discussed in further detail, as the city and port are located on the Avon just upstream of the Severn confluence, with a historical flood chronology constructed for the city by Bayliss and Reed (1999). Historic flood levels have been recorded at both Worcester and Shrewsbury since the late seventeenth century, with flood levels recorded on the Watergate at Worcester Cathedral since 1672, with 20 floods since marked on the wall, the most recent being the flood of December 2014. During the medieval period, the River Severn remained tidal beyond Worcester, but the tidal limit was subsequently moved below the city with the installation of the weir at Diglis in 1844 (Herbert, 1988). To reduce the uncertainties presented by the tidal signal, the flood reconstruction is undertaken for Bewdley, situated between the cities of Worcester and Shrewsbury and the site of the long gauged series (1921-present); an additional long series is available for Welsh Bridge at Shrewsbury (1911-present).

A rating curve constructed from flood marks at Worcester and the gauged flows at Bewdley is used to estimate the discharges for flows before 1921 back to 1672 (seven marks), with the cross section at Worcester considered to be relatively stable through this period based on analysis of historic maps, including that of John Speeds from 1610. The flood of 1795 is notable for its absence on the Watergate; Green (1796) notes the flood waters "rose to precisely those of 1672" and that a plate marking the level was added to the wall of North Parade, while the "New Bridge" built in 1781, became jammed with ice and caused extensive local flooding. The flood is documented at Gloucester as reaching within 6 inches $(15 \mathrm{~cm})$ of the level achieved in 1770 (Star, 1795). Whilst the floods are estimated back to 1672 , only those since AD 1750 will be used within this paper. 


\subsection{River Thames}

The River Thames presents one of the most heavily managed and modified river systems within Europe. An extensive historical chronology of flooding is available for London, but this is a particularly challenging site to reconstruct a single flood series for, as tidal influences are particularly strong and over the last millennium development of both banks and loss of surface tributary systems have changed the hydraulics of the system. Reconstruction of a complete flood history of the Thames at London would be a colossal task (see Galloway, 2009, for an analysis of the period 1250-1450), though the historical archive is unparalleled within a British context, with over 2000 accounts known. The current tidal extent of the Thames is Teddington weir/lock, which dates to 1811 , with a gauged series from 1883 to present (39001), a catchment area of $9948 \mathrm{~km}^{2}$ and average annual rainfall of $710 \mathrm{~mm} \mathrm{a}^{-1}$. Historically, the tidal extent was a weir constructed between the Old London Bridge (1209-1831) arches, following the removal of the weir during bridge reconstruction in 1831, seawater could reach Teddington Lock. The bridge constructed in ca. 1209 replaced several earlier timber structures. The channel during this period was much wider and shallower facilitating more frequent freezing of the river as described by Jones (2008) and illustrated in the renowned The Frozen Thames by Abraham Hondius (1677) and in Claude de Jongh (1632) View of London Bridge, in which the weir beneath the arches is evident. By the seventeenth century the city of London was starting to develop its quays and docks along the banks and therefore confined the river, as evident in Morgan's (1682) map of The Whole of London. By the publication of the map by John Rocques (1746), the channel is increasingly confined, particularly adjacent to London Bridge. The map of Bacon (1868) clearly illustrates the development of the Embankment reach, with further constriction of the river and extensive development and expansion of the city both up and downstream of the bridge area. The Embankment development further influenced the channel hydraulics, with constriction of the channel resulting in channel deepening, increasing the flow of water, which likely reduced opportunities for ice development (Jones, 2008). The Thames catchment land use consists of extensive arable farming in the headwaters and a number of urban centres upstream of London, including Reading, Swindon and the Oxford. The geology consist of Jurassic limestone and chalk outcrops, with thick alluvium and clays in the vales (Marsh and Hannaford, 2008).

Teddington Lock contains one of the most studied gauged series in the British Isles, with the largest gauged flow of 1894, originally estimated by Symons and Chatterton (1895) as 20135.7 million gal day ${ }^{-1}$ (equivalent to $1064 \mathrm{~m}^{3} \mathrm{~s}^{-1}$ ), within which a spatial analysis of the contributing tributaries and the relative ranking of 1894 on these systems and throughout the catchment was undertaken. This discharge was subsequently reassessed by Marsh et al. (2005) based on an extensive review of the information available for the flood and the channel geometry, with a revised discharge estimate of $806 \mathrm{~m}^{3} \mathrm{~s}^{-1}$. Whilst 1894 is the largest gauged flow, a number of historic floods can be attributed to heights relative to this event, with 1593 (substantially exceeded 1894), 1774 (about 12 inches higher), 1809 (12 inches higher) and 1821 (10 inches higher) all noted as being greater than that of 1894 (Beran and Field, 1988; Marsh and Harvey, 2012). Other notable floods also occurred in 1765, 1768, 1770, 1795, 1852, 1875 and 1877, as identified by Symons and Chatterton (1895). An analysis of the descriptive accounts indicates that the largest flood since AD 1750 is likely to have been that of 1809 based on the descriptive account, with an estimated discharge of $875 \mathrm{~m}^{3} \mathrm{~s}^{-1}$. A number of epigraphic flood marks have been identified around London; the 1774 flood mark located on the wall at Radnor Gardens, Twickenham, appears to be the earliest, with G. B. Laffan (1895) noting the level as being $0.85 \mathrm{~m}$ higher than that of 1894 . Symons and Chatterton (1895) recognised that the tidal influence present in 1894 was considered higher; therefore, an estimated discharge of $850 \mathrm{~m}^{3} \mathrm{~s}^{-1}$ is used for 1774 based on the reanalysis undertaken by Marsh et al. (2005). The floods of 1795 and 1821 appear relatively similar in description, with both appearing to be fractionally greater than 1894 in the lower catchment; therefore, a notional discharge of $825 \mathrm{~m}^{3} \mathrm{~s}^{-1}$ is used for both events. It is worth noting that Beran and Field (1988), considered the 1821 event to be the largest of the three events to have exceeded that of $1894\left(806 \mathrm{~m}^{3} \mathrm{~s}^{-1}\right)$. The historical floods 1768, 1770, 1852 and 1875 appear to be similar in magnitude, some slightly higher/lower in particular river reaches, but similar once past Windsor (Griffiths, 1969), and therefore for the purposes of this paper are all given an estimated discharge of $650 \mathrm{~m}^{3} \mathrm{~s}^{-1}$ based on descriptive accounts, i.e. lower than that recorded in $1947\left(714 \mathrm{~m}^{3} \mathrm{~s}^{-1}\right)$ but greater than $1968\left(600 \mathrm{~m}^{3} \mathrm{~s}^{-1}\right)$. Channel changes, river modification and uncertainties involved in estimating discharges makes the ranking of events challenging; therefore, these are estimated magnitudes based on the ranking of events for the area around Kingston upon Thames and should be used as indicative.

\subsection{River Ouse (Sussex)}

The Sussex Ouse flows south through the Downs into the English Channel at New Haven, past the principal settlements of Uckfield and Lewes. The catchment is predominantly rural, consisting almost entirely of ground beneath $150 \mathrm{~m} \mathrm{AOD,}$ with established forestry in the upper catchment. Few notable impoundment structures are present within the Sussex Ouse catchment, the exceptions being Ardingly Reservoir constructed in 1978 (impounding $\sim 20 \mathrm{~km}^{2}$ ) in the headwaters and the Ashdown and Barcombe reservoirs located between the forest of St Leonards and the lowland floodplain ( $\sim 5 \mathrm{~km}$ upstream of Lewes). The tidal limit is at Barcombe 
Mills ( $\sim 6.5 \mathrm{~km}$ upstream of Lewes) above the confluence of the Sussex Ouse and River Uck, with mean high water $3.5 \mathrm{~km}$ downstream of Lewes. The lower Sussex Ouse valley consists of thick alluvium overlying chalk, with an underlying mixed geology in the upper catchment. Precipitation is largely determined by elevation, with the northern sections along the South Downs receiving $\sim 1000 \mathrm{~mm} \mathrm{a}^{-1}$ and the coastal region receiving $\sim 730 \mathrm{~mm} \mathrm{a}^{-1}$. A long history of river management downstream of Lewes exists, reflecting the active shingle spit, which episodically impedes drainage of the lower Ouse through to the English Channel, with phases of extensive flooding and drainage documented (Brandon and Short, 1990; Woodcock, 2003). The numerous activities culminated in the 1790 Ouse Navigation Act, which would straighten (canalise) the Sussex Ouse at various points, in addition to providing drainage structures, which would prevent sediment supply to the shingle spit. The eventual result of the canalisation was $35 \mathrm{~km}$ of canalisation channel, 19 locks and a $1.3 \mathrm{~km}$ branch, with navigation up to Balcombe. The consequence on the hydraulic capacity of the channel during high-magnitude events is poorly detailed, though historical accounts continue to document overbank flooding during events comparable to that described by Pearce (2002) of extensive flood plain storage upstream of Lewes during flooding in 2000. The town of Lewes also floods from the Winterbourne Stream, which emerges from the chalk aquifer during periods of high groundwater; therefore, it can flood in combination with, or independently of, the Sussex Ouse.

Three bridges span the Sussex Ouse in central Lewes: (i) Cliffe Bridge, which is the oldest bridge and is the site of several historical bridges in Lewes (commonly known as Ouse Bridge), which probably reflects the location of a ford, ferry and Roman bridge (Dunvan, 1795; Salzman, 1940); (ii) Willey's Footbridge (opened in 1965); and (iii) the Phoenix Causeway (a larger road bridge built in the early 1970s). The modern A27 trunk road crosses the Sussex Ouse to the south of Lewes, together with a railway bridge, but these have a limited impact on the hydrology at Lewes. Accounts detailing the repair of a bridge in Lewes exist from AD 1159, with the bridge rebuilt in 1561 and repaired in 1652, both coincide with accounts of extensive flooding (Dunvan, 1795). Historical accounts detail the bridges destruction in 1726 (Sawyer, 1890), with the current single stone arch structure dating from 1727, with widening work undertaken in 1932 (Salzman, 1940). The adjacent wharf was constructed in 1770-1771 and subsequently repaired in 1802 (Salzman, 1940), suggesting little change in the channel cross section at Lewes during the intervening period; the first Ordnance Survey (1875) map of Lewes shows little change in channel location and adjacent structures to the present day. Based on the documents and maps available reasonable confidence can be placed in the cross sectional area of the channel at Lewes remaining relatively stable since ca. 1750, a time frame comparable to that selected in previous studies (e.g. Parent and Bernier, 2003; Macdon- ald, 2013). The historical accounts of flooding provide detailed descriptive accounts of past flood extents, which can be converted into levels augmenting the discharge readings from 1960 for the Isfield (41006; Uck) and Gold Bridge (41005; Ouse) gauging stations $\left(\mathrm{m}^{3} \mathrm{~s}^{-1}\right)$. A detailed discussion of the flood history and flood series reconstruction is provided by Macdonald et al. (2014).

\subsection{River Exe}

The River Exe drains the upland regions of Dartmoor, Exmoor and the Blackdown Hills in southwest England (Fig. 1), with most of the catchments underlying geology consisting of relatively impermeable Carboniferous shales and slates (British Geological Survey, 1995). Exeter is the principal settlement on the River Exe, with a history predating Roman times (Hoskings, 1960). The city of Exeter is situated at the tidal extent, with an extensive history of human activity on the floodplain (Brown et al., 2010), including historic fording and medieval bridges, the oldest dating from the end of the twelfth century; a detailed discussion of bridging at Exeter is provided by Brierley (1979), which includes a discussion of historic bridge damage and maintenance closely tied to flood events. Catchment land use is predominantly agricultural and rough grazing, with limited urban development. The River Exe at Exeter consists of three principal sub-catchments, the Exe flowing from the north $\left(\sim 600 \mathrm{~km}^{2}\right)$, the Culm, which enters the Exe just upstream of Exeter from the west with a catchment area of $\sim 250 \mathrm{~km}^{2}$, and the Creedy, which flows from the east and also enters the Exe just upstream of Exeter, with a catchment area of $\sim 260 \mathrm{~km}^{2}$. The only significant impoundment structure in the headwaters of the Exe is Wimbleball lake in the River Haddeo sub-catchment, which was constructed in 1979 and has a volume of $\sim 21000 \mathrm{~mL}$ and a catchment area of $29 \mathrm{~km}^{2}$ (Webb and Walling, 1996). Precipitation is greatest $\left(>1400 \mathrm{~mm} \mathrm{a}^{-1}\right)$ over the uplands, dropping to $\sim 850 \mathrm{~mm} \mathrm{a}^{-1}$ at Exeter Airport near the coast ( $\sim 25 \mathrm{~m}$ AOD). The geology and relatively steep gradient have resulted in a fluvial system with a flashy flood regime; a detailed discussion of channel form is provided by Bennet et al. (2014), including copies of the city maps from John Hooker's map of 1587 through to those of the early nineteenth century, detailing the instability within the lower channel with high rates of channel movement across the floodplain, with greater stability since the nineteenth century.

A set of gauged records exists for the River Exe at Thorverton (45001) since 1956, $\sim 11 \mathrm{~km}$ upstream of Exeter (Marsh and Hannaford, 2008), the Culm at Wood Mill (45003) since 1962, $15 \mathrm{~km}$ upstream of Exeter and at Cowley (45012) on the Creedy since 1964, $\sim 3 \mathrm{~km}^{2}$ upstream of Exeter. These gauged series are combined to generate a single series for the site, instantaneous peak flow (ipf) data are used where available, where gaps are present mean 95 daily flow (mdf) are included, whilst under-representing peak flow this provides a conservative discharge estimate, 


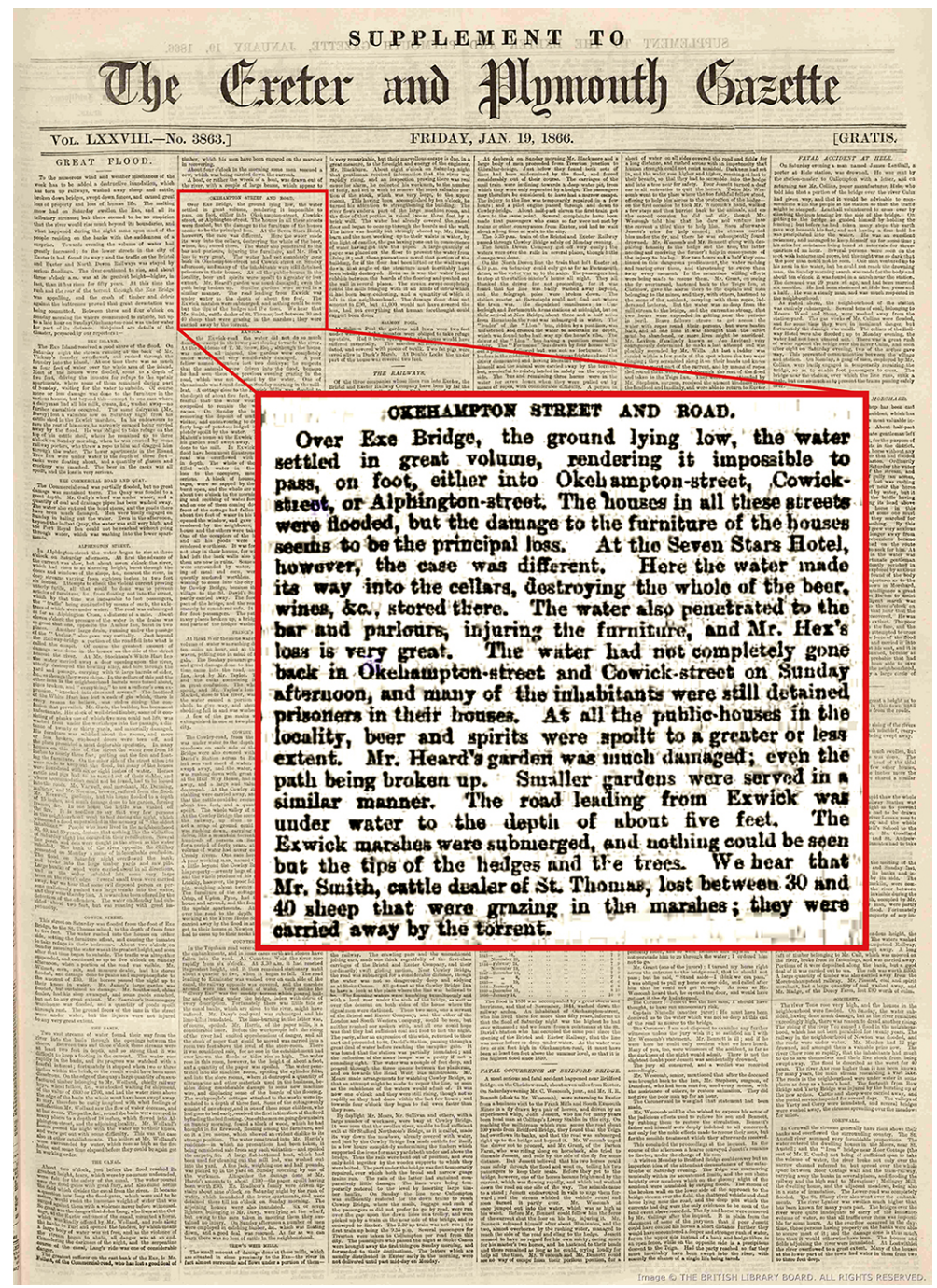

Figure 3. An example newspaper supplement dedicated solely to the flooding of the River Exe, January 1866. Enlarged section highlights the detailed local-level information contained within the supplement (Exeter and Plymouth Gazette, 1866).

with only two years recording no ipf at any station, where ipf are within 1-day of each other at the sites, these are used as they provide a better depiction of the highest flows. It should be noted that the two tributaries (Creedy and Culm) have flashy regimes, which can produce high ipf, but may still have relatively low mdf, whereas the main River Exe has a less flashy discharge regime. The highest combined flow during the instrumental period is $722 \mathrm{~m}^{3} \mathrm{~s}^{-1}$ (2000), which using the descriptive accounts as a guide was initially estimated at $700 \mathrm{~m}^{3} \mathrm{~s}^{-1}$ at Exeter. A number of well-documented flood events during the gauged series, particularly 1960 with subsequent events in 1974, 1985, 2000 and 2002, provide valuable guidance on past event magnitudes at Exeter, with a number of historical events being documented to a high level, e.g. the flood of January 1866, for which the local newspaper Exeter and Plymouth Gazette (1866) produced a separate supplement detailing the extent and impact of flood events around the country in both urban (Exeter) and rural areas (Fig. 3). Izacke (1676) provided the first discussion of flooding at Exeter with a number of historic floods detailed, with the first reported (unsupported) in AD 12. As at previous sites, greater confidence can be placed in the discharge estimates since 1750 as channel form is more stable, with highmagnitude events. As at previously described sites, the estimated discharges of the pre-instrumental series are derived from the relative extent, level and damage caused by historic floods relative to the associated damage and extent of floods within the gauged period.

\section{Series composition}

The absence of flood record(s) for any given year does not necessarily indicate flooding did not occur, simply that no 


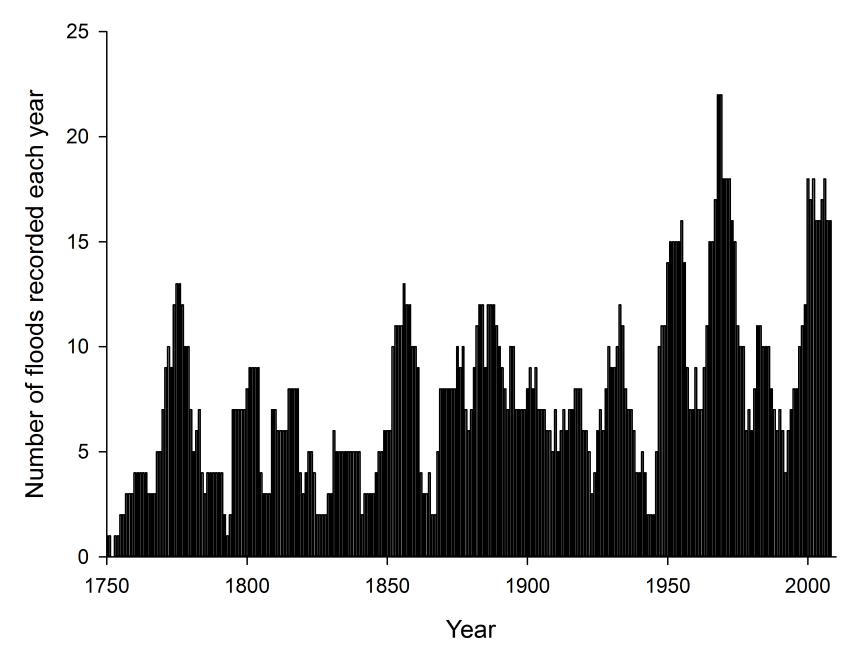

Figure 4. Number of floods with a recorded/estimated discharge exceeding the 0.9 threshold.

record of flooding remains, or the account(s) included insufficient detail to provide an estimation of the flow. However, it is likely that the largest events have been included since ca. AD 1750, as recording becomes more systematic, with greater confidence given to high-magnitude floods. Significant growth in documentary recording during the mideighteenth century corresponding to newspaper distribution growth has previously been identified (Williams, 2009); as indicated by Fig. 4 the frequency of severe flood recording appears to be relatively stable from 1750 .

Documentary flood records frequently include basic information concerning date, height or magnitude of events, and often the causative mechanism, i.e. rain, thaw or a combination of the two (McEwen, 1987). The presence of long flood records results from several influences, namely the presence of literate individuals linked to monastic, political and economic activities within the cities; a detailed discussion of sources are provided in Archer (1999) and Macdonald (2004, 2007) among others.

\section{Flood thresholds}

Whilst much research has focussed on the impact of land use on relatively small flood events (e.g. Climent-Soler et al., 2009), little research, either modelled or field instrumented, has attempted to undertake this analysis with rarer highmagnitude events. Wheater and Evans (2009) postulated that the impact of urbanisation is potentially reduced during large flood events, whilst O'Connell et al. (2004) identify that there is very limited evidence that local changes in runoff propagate downstream. Knowledge of the conditions (climate, channel form, anthropogenic influence, upstream catchment activity, etc.) from which events were recorded is important in considering the value of contemporary or historical flood information. When dealing with extreme flooding at
York, Macdonald and Black (2010) identified that there have been a number of phases of increased flooding (flood rich) and periods of reduced flooding (flood poor) throughout the historical record. Therefore, the argument has been made that once long periods are considered ( $>\sim 200$ years) variability becomes inescapable, and that inclusion of flood-rich and flood-poor periods leads to more robust flood frequency estimates. The changing nature of climate and catchment land use throughout the historical period may have caused many changes within the river regime, potentially manifesting as "flood-rich" and/or "flood-poor" periods (Starkel, 2002; Benito and Thorndycraft, 2005). However, at York Macdonald and Black (2010) identified a phase of increased flooding around $\mathrm{AD} 1625$, but no significant change in flood frequency over the period AD 1800-2000. A view supported at a European scale by Mundelsee et al. (2003), but contrasting to the findings by Macklin and Rumsby (2007) when examining British upland catchments, as they identified a decrease in flood frequency based on geomorphologically inferred flood events over the last 50 years.

\section{$5 \quad$ Flood indices (FI)}

Distinguishing between an increase in flood records from anthropogenic factors (resulting from a number of social, cultural and political factors; Williams, 2009) and an increased frequency resulting from a hydroclimatic change in highmagnitude flood events is challenging, particularly over long timescales. A new method is proposed here that accounts for the changing frequency of recording through time (increasing nearing the present), which allows for growth in recording number, without assuming that this is linear. First, two distinct time frames are identified within the historical flood records over the last millennium for British Isles, reflecting the prevalence of account preservation and frequency in AD 1000-1750 and AD 1750-present; within this paper the period AD 1750-present only is considered. The growth in flood recording rises from a 10-year count of 0 records (AD 1752) to 22 records in AD 1968 and 1969. The flood indices (FI) (Eq. 1) are calculated for each year, for all floods that exceed a threshold ( $>0.9$ percentile). A 10-year window of analysis $\left(\bar{z}^{10}\right)$ is used to reduce the likelihood of a single flood-rich year appearing as a flood-rich period.

$\mathrm{FI}_{t}=\bar{z}_{t}^{(10)}\left(1-\frac{t}{e}\left(\frac{\max (z)-\min (z)}{n}\right)\right), t=1,2, \ldots, n$,

where $z$ is the number of flood events recorded in any given year above the threshold (e.g. 0.9 percentile), $\bar{z}^{10}$ is the mean number of flood records within the preceding 10 -year period above the threshold, $n$ is the total number of years within the study period $t, t$ is the number of years after the start of the period (e.g. 1760 is 10) and $e$ is total number of flood events above the threshold in $n$. 
Threshold selection is subjective; in Fig. 5 both thresholds for 0.8 and 0.9 are shown for illustrative purposes. This paper is particularly interested in high-magnitude flood events; therefore, the following discussion will focus on flood events exceeding the 0.9 percentile threshold.

\section{Spatial and temporal flood variability}

The flood series are compiled from archival materials and previously published series for the rivers Findhorn (McEwen and Werritty, 2007), Tay (Werritty et al., 2006; Macdonald et al., 2006), Tweed (McEwen, 1990), Tyne (Archer et al., 2007), Eden (Macdonald, 2006; Patterson and Lane, 2012), Dee, Yorkshire Ouse (Macdonald and Black, 2010), Trent (Macdonald, 2013), Severn, Thames, Sussex Ouse (Macdonald et al., 2014) and Exe (Fig. 5). An additional chronology for the River Kent in the southern Lake District has been constructed, but is relatively short compared to those presented here and is therefore not included. In each case the estimated discharges are derived from historical accounts and records, where previous studies have been conducted the original archive materials are considered, a detailed review of the different materials and chronologies for each site is beyond the scope of this paper (please refer to cited papers in site-specific sections, Sects. 3.1-3.12). These series represent the sites for which the most detailed and complete historical series exist; the Thames reconstruction is based at Teddington above the tidal limit, as determining the influence of tidal input to the historical floods in London is challenging, though the potential of the historical flood record at London is considerable.

The individual flood series are compiled into grouped series at a range of spatial scales: national (all sites); east (Tay, Tweed, Tyne, Ouse-Yorkshire, Trent, Thames) and west (Findhorn, Eden, Dee, Trent, Severn, Exe) draining catchments; and Wales (Dee and Severn), Scotland (Findhorn, Tay, Tweed), northern (Eden, Tyne, Ouse-Yorkshire, Trent) and southern England (Thames, Exe, Ouse-Sussex), permitting further detailed regional analysis (Fig. 5). The focus on relatively large catchments, within a British context, inevitably constrains the generating mechanisms that are likely to result in high-magnitude floods, which are likely to be either snowmelt, persistent/heavy rainfall on saturated/frozen ground, or a combination of the two (Black and Werritty, 1997); intense rainfall events generally have greater impact on small catchments with high relief, although subcatchments of those studied may contain high relief, these are unlikely to result in significant flood events at the sites examined. The potential role of snowmelt as a flood generating mechanism since AD 1800 with the Yorkshire Ouse has been examined (Macdonald, 2012), with the ratio of floods deriving a snowmelt component found to be consistent, though potential changes in accumulation within the upper catchment may vary (no records exist of snow depth). The role of ice jamming in Britain as a cause for significant flood events is limited, with only the 1814 flood on the River Tay clearly exacerbated by ice floes (jamming under Smeaton's Bridge, see Macdonald et al., 2006), though historical accounts identify a number of ice fairs held on several of the rivers over the period of study. The seasonality of flood events is an important factor in considering the nature of the floods experienced, with many of the papers identified within the catchment sections above discussing this in greater detail. Further analysis examining flood seasonality changes across Britain over longer timescales is required, though most flood events occur in the winter season across Britain (Black and Werritty, 1997; Macdonald et al., 2010a).

Of the sites considered within this paper, no site incorporates a large groundwater component during extreme events, with the Thames and Sussex Ouse potentially including a greater groundwater contribution than other sites as detailed above. The Thames catchment may experience localised groundwater flooding, but this is small relative to the flows within the main channel and localised within the catchment; similarly the Sussex Ouse receives limited groundwater flooding, with groundwater flooding from the Winterbourne stream tributary affecting a specific area of Lewes downstream of the point considered within this study.

\section{Flood-rich and flood-poor phases}

Discernible flood-rich periods have been identified at a national scale, across multiple catchments and within specific catchments since AD 1750 (Fig. 2). The regional FIs (Fig. 5) show both coherent flood-rich phases (e.g. 1770s) across most catchments, but also regionally specific flood-rich periods (e.g. Wales, ca. 1883). The division of Britain eastwest shows similar patterns in the FI, with some subtle differences, e.g. stronger flooding signal ca. 1770 in eastern Britain, though overall it illustrates that there are not considerable differences in flooding on an east-west basis. Division into four regions provides more variability and permits an assessment of spatial variability, with clear differences in FI for Scotland and Wales, with the flood peak around 1883 in Wales not evidenced in Scotland and a lower FI score for the 1853 event in Wales than in Scotland. The northern and southern Britain divisions have also shown considerable differences, particularly for the period since 1950, with considerably more events in the north during this period. Consideration of the regional flood-rich periods, as indicated by the black boxes on the right vertical axis (Fig. 5) illustrates the temporal and spatial variability of flood-rich periods across Britain.

National flood-rich periods are identified during the periods of the 1850s and 2000-present, with several short floodrich phases: $1765-1780,1850 \mathrm{~s}$, late 1940s and mid-1960s. High-magnitude floods in the mid-to-late nineteenth century have been widely documented across Britain (e.g. Brookes and Glasspoole, 1928), with the period AD 1875-1885 iden- 


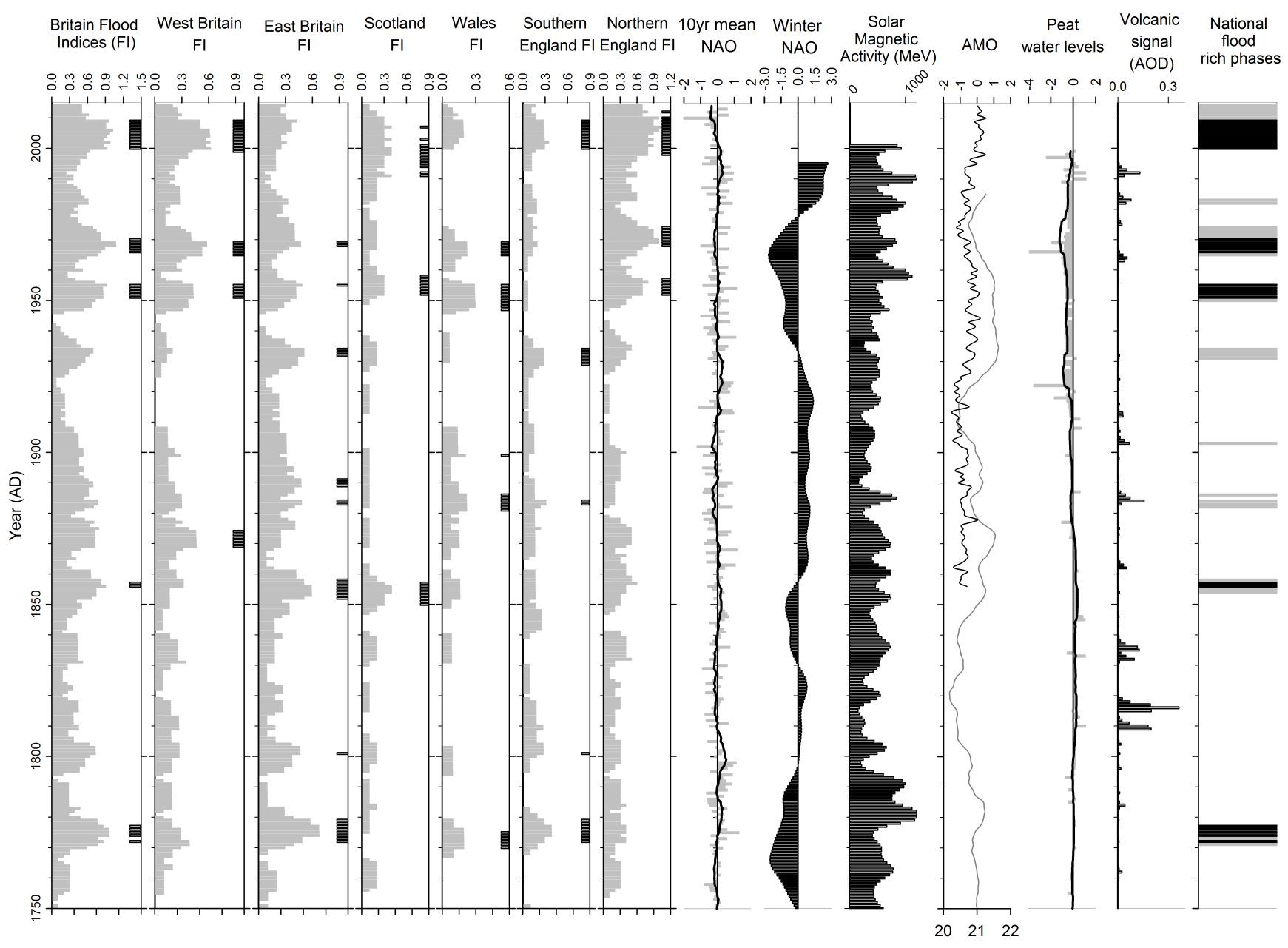

Figure 5. Historical flood chronologies (grey) by region and associated flood-rich periods (black) - Britain (1750-2014): west Britain FI (flood index); east Britain FI; Scotland FI; Wales FI; northern England FI; southern England FI; NAO reconstruction (with 10-year-running mean; Luterbacher et al., 2002); extended with CRU data; winter NAO (Trouet et al., 2009); solar magnetic (MeV; Muscheler et al., 2007); AMO grey (Gray et al., 2004) and black (Enfield et al., 2001); annual stacked peat water level (10-year-running mean; Charman et al., 2006); volcanic signal derived from aerosol optical depth (AOD; Crowley and Unterman, 2012); and national flood phases, using a 0.9 threshold (black) and 0.8 (grey).

tified as including a number of years with severe floods (Marsh et al., 2005), though this period is not identified when applying a 0.9 (black) percentile threshold; if the threshold is lowered to 0.8 (grey), this period appears as flood rich (Fig. 5). The current flood-rich period (2000) is of particular interest with several extreme events documented in recent years, though it should be noted from a historical perspective that these are not unprecedented, with several periods with comparable FI scores since ca. 1750, it remains unclear at present whether the current period (2000) represents a short or long flood-rich phase. It is notable that the current flood-rich phase is more evident in northern rivers than those of the south, though several of the southern rivers examined recorded high flows in winter 2014. The severe floods of December 2015 are not included within the series, as data are unavailable for all sites, but resulted in record breaking discharges in several of the catchments; it is worth noting that gauged discharges on the Eden and Tyne are the highest recorded (est. $\sim 1700 \mathrm{~m}^{3} \mathrm{~s}^{-1}$ ) and third highest on the Tweed (est. $\sim 1361 \mathrm{~m}^{3} \mathrm{~s}^{-1}$; CEH, 2016), all of which are northern England catchments. The spatial coherence of the FI varies, illustrating the importance of good spatial coverage, and suggests that an understanding of flood-rich periods needs to be undertaken first at a catchment scale, with subsequent studies examining larger areas/regions. The spatial variability in the series suggests that regions are behaving differently, with periods of synchronous (e.g. national 1770s) and non-synchronous (e.g. regional 1920s) activity.

The FI (Fig. 5) generated for Britain corresponds well to events/periods recorded elsewhere within the literature containing significant flood events, whereas other proxy series fail to show clear relationships for the study period, e.g. the 
peat wetness record (Charman, 2010). In the context of the long historical flood series available for mainland Europe, flooding appears to be synchronous and asynchronous during different phases in comparison to the British series. Benito et al. (2004) identified flood-rich periods for the Tagus river in southern Spain during the periods 1730-1760, 1780-1810, 1870-1900, 1930-1950 and 1960-1980 (italics coinciding with British flood-rich periods at a 0.9 threshold). The Sheffer et al. (2008) study of the Gardon river in southern France identified several flood-rich phases: 1765-1786, 1820-1846, 1860-1880 and 1890-1900, where Llasat et al. (2005) identified flood-rich phases for Catalonia in 1760-1800 and 1830 1870. The comparison of the British FI to the historical flood series presented by Glaser et al. (2010) for central Europe shows a more complex story, with a number central European systems appearing to be asynchronous in relation to the British (e.g. Vistula), whilst others provide similar flood-rich and flood-poor phases (e.g. Rhine). The mid-to-late eighteenth century flood-rich phase in Britain coincides with a longer flood-rich phase in central Europe from 1730-1790 (Glaser et al., 2010), with other phases identified (17901840 coincide with periods of little flooding in Britain). Brázdil et al. (2005) identified a series of flood phases on the Vltava in Prague, with peaks ca. 1750, ca. 1825, 1840 1860, 1890, 1940-1950 and 1975-1990, again showing some overlap with flood-rich periods witnessed in Britain, but also periods of little flood activity, e.g. 1975-1990. Wetter et al. (2011) identified a number of large floods for the Rhine: ca. 1740-1791, 1850-1880, 1994-2007; of the published flood series this shows good comparison to the British FI. Few studies have examined the flood history of Irish rivers; an account of the history of Dublin (Dixon, 1953) identifies a number of floods associated with bridge damage/destruction, with subsequent events in 1794, 1802, 1807, 1851 and 1931, though it is difficult to ascertain any further information from these accounts other than event occurrence. Tyrell and Hickey (1991) identified the three most severe floods in Cork, southern Ireland, as 1789, 1853 and 1916, with increases in flood frequency in the 1920s, 1930s and 1960s. Whilst both the Tyrell and Hickey (1991) and Dixon (1953) studies provided some information for Ireland, it is challenging to determine whether these are small- or wide-scale flood-rich periods, with the flood-rich phase in Dublin of the mid-eighteenth century occurring before that in Britain, the increased frequency in Cork in both 1920s (apparent at 0.8 threshold) and the 1960s and large flood of 1853 both coincide with those identified in the British FI.

\section{Flood drivers}

During much of the Holocene, three forms of natural forcing of climate have been evident: orbital (Esper et al., 2012), solar (Lean, 2000; Vaquero, 2004) and volcanic (Brázdil et al., 2010), which have influenced the global climate, and there- fore potential flood generating mechanisms. Orbital forcing over the last millennium has changed little.

Solar forcing can manifest itself in a variety of different ways on flood patterns through modification of the climate (Benito et al., 2004). Several series (Fig. 5) indicated increased flood frequency during the late eighteenth century corresponding to the Dalton Minimum (AD 1790-1830), with notable flooding across catchments in the 8-year period AD 1769-1779, which was a climatic period considered to include the sharpest phases of temperature variability during the "Little Ice Age" (Lamb, 1995; Wanner et al., 2008). The spatial and temporal variability in relation to these events may suggest that snowmelt becomes a more important driver for flooding relative to heavy precipitation, suggesting that flood response to solar forcing may be regionally and temporally heterogeneous (Benito et al., 2004). A positive significant relationship exists $(p>0.95)$ between solar irradiance (Lean, 2000) and FI national and north, west, Scotland and Wales regions (AD 1750-2014; Fig. 5; $p=<0.0012$ ). A significant positive correlation between Atlantic Meridional Oscillation (AMO; 1850-present; Enfield et al., 2001, updated by NOAA) and national FI is identified $(p=<0.0001)$, with significant positive regional correlations also identified for the north, south, Scotland and west FI at both annual and winter/summer half-years $(p=<0.001)$. Analysis of dendro-chronological reconstruction of AMO (Gray et al., 2004) since 1750 has identified significant positive correlations with regional FI west and FI Scotland, but not for other regions, or nationally

A significant negative correlation $(p=<0.001)$ between north and Wales FIs, and winter North Atlantic Oscillation Index (NAOI) since 1750 has been identified, with the east and west FIs exhibiting a negative correlation $(p=<0.02$; Trouet et al., 2009). These findings correspond to previous studies, which have attributed flood-rich phases to both positive (Dixon et al., 2006; Hannaford and Marsh, 2008) and negative (Macklin and Rumsby, 2007; Folland et al., 2009; Foulds et al., 2014) phases of the NAOI, though these studies have used different river flow series, with those evidencing positive NAOI relationships often using short instrumental series (ca. 1960); conversely, those evidencing negative relationships have applied palaeo-historic-geomorphic flood series for several centuries. This suggests that the relationship between NAOI and flooding is complex, with potentially different flood generating mechanisms, or potentially different flood magnitudes, responding to different NAOI states, with different levels of threshold of inclusion being used in the different datasets considered. The relationship identified within this paper suggests that historical high-magnitude floods occur during phases of negative NAOI (Fig. 5); specific floodrich periods identified in the British FI correspond to negative (e.g. late 1960s) and positive (e.g. ca. 1770) phases of NAOI. The significant correlations identified above indicate that warming of the Atlantic through solar forcing has potentially resulted in changes to flood phases, with the pres- 
ence of flood-rich phases across multiple catchments suggesting abrupt changes in flood frequency/magnitude, reflecting wider climatic variability, which permits an assessment of regional palaeo-climatic change (e.g. Schillereff et al., 2014). This represents an important finding, with potential future implications for flood type, with a warmer Atlantic potentially leading to greater potential energy that may result in an increase in intense precipitation events, resulting in high-magnitude floods affecting Britain, with areas particularly vulnerable being coastal uplands in the southwest, southern Wales and the Lake District, with recent notable floods (2005, 2009 and 2015) in the latter.

Aerosol optical depth was used as a proxy for volcanic forcing (Crowley and Unterman, 2012), with no relationship evident to the British or regional FI. The British FI fails to identify a relationship between large volcanic events and flooding in Britain (e.g. Laki Fissure, 1784; Krakatoa, 1883 and Tarawera, 1886; Fig. 5). The clear peak in AOD following the Tambora (Indonesia) eruption of 1815 results in elevated AOD for several years (Fig. 5), whilst there have been clearly documented impacts felt across Europe in relation to temperature, with the "year without a summer" (Oppenheimer, 2003); no evidence is presented from the British flood chronologies of any associated change in flood magnitude or frequency. The widespread flooding documented across much of central Europe during the winter of $\mathrm{AD}$ 1783-1784 following the Laki fissure (Iceland) eruption is not widely evidenced within British catchments (Brázdil et al., 2010). Overall, there appears to be little evidence in British systems of volcanic forcing influencing flood events directly during the period of study.

\section{Summary}

The apparent increase in flooding witnessed over the last decade appears in consideration to the long-term flood record not to be unprecedented; whilst the period since 2000 has been considered as flood-rich, the period 1970-2000 is "flood poor", which may partly explain why recent floods are often perceived as extreme events. The much publicised (popular media) apparent change in flood frequency since 2000 may reflect natural variability, as there appears to be no shift in long-term flood frequency (Fig. 5). In reviewing the flood series for European systems for which long flood series have been reconstructed, a complex picture is identified; whilst flood-rich phases appear synchronous across many systems (1765-1780) others show less synchronicity (1920s), whereas a number of prominent floodrich phases at a European scale appear subdued or are not evident in the British FI (1750s).

The principal findings of this work are that of the strong correlations between flood-rich/flood-poor phases and solar magnetic activity, AMO and NAOI, indicating a clear driver for flooding patterns across Britain. The specific mechanisms that govern the relationship between the spatial/temporal distribution of flood clusters and solar activity remain unclear. This work suggests that high-magnitude flood-rich periods relate to negative NAOI across much of the country, in western catchments with a stronger westerly airflow signal significantly correlating to positive NAOI, with reasonable correspondence with previously diagnosed periods of climatic variability identified from individual series from across $\mathrm{Eu}-$ rope. It also identifies the importance of the Atlantic Multidecadal Oscillation as a clear correlation is shown between higher North Atlantic sea temperatures and increased severe flood events across much of Britain. It is worth noting that when the threshold is reduced to the 0.8 percentile of events (Fig. 5), significant correlations remain between the British FI and summer, winter, annual AMO (1850) and NAOI (Trouet et al., 2009). The inclusion of historical flood information provides a better understanding of long-term flood patterns. The detection of flood-rich periods and attribution to periods of climatic change are tentative. The historical records still hold a wealth of untapped information for which specific discharges cannot be estimated, but from which indices could be extracted in the future (Barriendos and Coeur, 2004). The wealth of information presented by the historical records presents valuable new information for flood risk assessment and management (Kjeldsen et al., 2014); as new flood chronologies become available, more detailed and complete indices-based chronologies will improve the resolution and enhance understanding of flood-rich and flood-poor periods, presenting a more complete depiction of the role of climate and extreme floods. Extending the records back to a millennial time frame is possible, providing valuable insights into long-term trends and patterns of flood frequency and potential climatic drivers of flooding.

\section{Data availability}

Discussions are currently ongoing concerning the deposition of the final datasets; this is in part constrained by the requirements of data ownership of the gauged hydrological data.

Competing interests. The authors declare that they have no conflict of interest.

Acknowledgements. This research was in part funded by a NERCCASE studentship (NER/S/C/2000/03289) and a RGS-IBG/EPSRC Geographical Research Grant EPSRC 3/05 to Neil Macdonald. The assistance of the National River Flow Archive at CEH Wallingford and Scottish Environment Protect Agency in provision of contemporary gauged river flow data is greatly appreciated. Thanks to Thomas Kjeldsen for reading a draft of the paper. Thanks are also given to the numerous anonymous reviewers, who provided thoughtful comments. 
Edited by: A. Kiss

Reviewed by: four anonymous referees

\section{References}

Acreman, M. C.: Extreme Historical UK floods and maximum flood estimation, Water Environ. J., 3, 404-412, 1989.

Archer, D. R.: Improvement in flood estimates using historical flood information on the River Wear at Durham, British Hydrolo. Soc. Symp, First National symposium, 14-16 September 1987, Hull, 1987.

Archer, D. R.: Land of Singing Waters: Rivers and Great Floods of Northumbria, Spredden Press, Stocksfield, Northumbria, UK, 1992.

Archer, D. R.: Practical application of historical flood information in flood estimation, in: Hydrological Extremes: Understanding, Predicting, Mitigating, IAHS Publ. 255, edited by: Gottschalk, L., Olivry, J.-C., Reed, D., and Rosbjerg, D., IAHS Press, Wallingford, UK, 191-199, 1999.

Archer, D. R.: Tyne and Tide: A celebration of the River Tyne, Daryan Press, Ovingham, 2003.

Archer, D. R. Leesch, F., and Harwood, K.: Assessment of severity of the extreme River Tyne flood in January 2005 using gauged and historical information, Hydrolog. Sci. J., 52, 992-1003, 2007.

Archer, N.: Discharge estimate for Britain's greatest flood: River Tyne, 17 November 1771, BHS 4th National Hydrolo. Symp., 13-16 September 1993, Cardiff, 1993.

Bacon, G. W.: Map of London, G. W. Baco, London, 1868.

Barriendos, M. and Coeur, D.: Flood data reconstruction in historical times from non-instrumental sources in Spain and France, in: Systematic, Palaeoflood and Historical Data for the Improvement of Flood Risk Estimation, Methodological Guidelines, edited by: Benito, G. and Thorndycraft, V. R., Centro de Ciencias Medioambientales, Madrid, Spain, 29-42, 2004.

Bayliss, A. C. and Reed, D. W.: The use of historical data in flood frequency estimation, Centre for Ecology and Hydrology (NERC), Wallingford, 2001.

Beckett, J.: Nottingham: An illustrated History, Manchester University Press, Manchester, UK, 1997.

Benito, G. and Thorndycraft, V. R.: Palaeoflood hydrology and its role in applied hydrological sciences, J. Hydrol., 313, 3-15, 2005.

Benito, G., Diez-Herrero, A., and de Villalta, M. F.: Response to Solar Signal in the Number of Floods Recorded for the Tagus River Basin over the Last Millennium, Climatic Change, 66, 2728, 2004.

Bennett, J. A., Brown, A. G., and Reed, S. J.: Holocene fluvial geomorphology of the River Exe (UK) from archaeological and historical data and implications for urban form, Proc. Geol. Ass., 125, 639-648, 2014.

Beran, M. and Field, E. K.: Maidenhead, Windsor and Eton Flood Study, Inst. of Hydrol., Wallingford, p. 48, 1988.

Black, A. R. and Law, F. M.: Development and utilisation of a national web-based chronology of hydrological events, Hydrolog. Sci. J., 49, 237-246, 2004.

Black, A. R. and Werritty, A.: Seasonality of flooding: a case study of North Britain, J. Hydrol., 195, 1-25, 1997.
Böhm, O., Jacobeit, J., Glaser, R., and Wetzel, K.-F.: Flood sensitivity of the Bavarian Alpine Foreland since the late Middle Ages in the context of internal and external climate forcing factors, Hydrol. Earth Syst. Sci., 19, 4721-4734, doi:10.5194/hess-194721-2015, 2015.

Brázdil, R.: The History of Floods on the Rivers Elbe and Vltava in Bohemia, Erfurter Geogr. Stud., 7, 93-108, 1998.

Brázdil, R., Pfister, C., Wanner, H., Von Storch, H., and Luterbacher, J.: Historical climatology in Europe - the state of the art, Climatic Change, 70, 363-430, 2005.

Brázdil, R., Kundzewicz, Z. W., and Benito, G.: Historical hydrology for studying flood risk in Europe, Hydrolog. Sci. J., 51, 739764, 2006.

Brázdil, R., Demarée, G. R., Deutsch, M., Garnier, E., Kiss, A., Luterbacher, J., Macdonald, N., Rohr, C., Dobrovolný, P., Kolár, P., and Chromá K.: European floods during the winter 1783/1784: scenarios of an extreme event during the 'Little Ice Age', Theor. Apol. Climatol., 100, 163-189, 2010.

Brázdil, R., Kundzewicz, Z. W., Benito, G., Demarée, G., Macdonald, N., and Roald, L. A.: Historical floods in Europe in the past millennium, in: chap. 7, Changes of Flood Risk in Europe, edited by: Kundzewicz, Z. W., IAHS Press, Wallingford, UK, 121-168, 2012.

Brierley, J.: The mediaeval Exe bridge, Proc, Inst. Civ. Eng., 66, 127-139, 1979.

British Geological Survey: Exeter, England and Wales Sheet 325, Solid and Drift Geology 1:50000, Keyworth, Nottingham, 1995.

Brandon, P. and Short, B.: The South-East from AD 1000, Longman, London, 1990.

Brookes, C. E. P. and Glasspoole, J.: British floods and droughts, Ernest Benn Ltd, London, 1928.

Brown, A. G., Cooper, L., Salisbury, C. R., and Smith, D. N.: Late Holocene channel changes of the middle Trent: channel response to a thousand year flood record, Geomorphology, 39, 69-82, 2001.

Brown, A. G., Basell, L. S., Toms, P. S., Bennett, J. A., Hosfield, R. T., and Scrivner, R. C.: Later Pleistocene evolution of the Exe valley: A chronstratigraphic model of terrace formation and its implications for Palaeolithic archaeology, Quaternary Sci. Rev., 29, 897-912, 2010.

Bürger, K., Seidel, J., Dostal, P., Glaser, R., Sudhaus, D., and Mayer, H.: Extreme floods on the 19th century in southwest Germany, La Houille Blanche, 1, 67-73, 2007.

Camuffo, D. and Enzi, S.: The analysis of two bi-millennial series: Tiber and Po river floods, Climatic Variations and Forcing Mechanisms of the Last 2000 Years, NATO ASI Series, 41, 433-450, 1996.

$\mathrm{CEH}$ - Centre for Ecology and Hydrology: Briefing note: Severity of the December 2015 floods - preliminary analysis, Wallingford, UK, p. 5, 2016.

Charman, D. J.: Centennial climate variability in the British Isles during the mid-late Holocene, Quaternary Sci. Rev., 29, 15391554, 2010.

Charman, D. J., Blundell, A., Chiverrell, R. C., Hendon, D., and Langdon, P. G.: Compilation of non-annually resolved Holocene proxy climate records: Stacked Holocene peatland palaeo-water table reconstructions from northern Britain, Quaternary Sci. Rev., 25, 336-350, 2006. 
Climent-Soler, D., Holman, I. P., and Archer, D. R.: Application of flow variability analysis to identify impacts of agricultural landuse change on the River Axe, southwest England, Hydrol. Res., 40, 380-393, 2009.

Crowley, T. J. and Unterman, M. B.: Technical details concerning development of a $1200 \mathrm{yr}$ proxy index for global volcanism, Earth Syst. Sci. Data, 5, 187-197, doi:10.5194/essd-5-187-2013, 2013.

de Jongh, C.: View of London Bridge, V \& A Museum, London, 1632.

Demarée, G. R.: The catastrophic floods of February 1784 in and around Belgium - a Little Ice Age event of frost, snow, river ice and floods, Hydrolog. Sci. J., 51, 878-898, 2006.

Dennis, I. A., Macklin, M. G., Coultard, T. J., and Brewer, P. A.: The impact of the October-November 2000 floods on the contaminant metal dispersal in the River Swale catchment, North Yorkshire, UK, Hydrol. Process., 17, 1641-1657, 2003.

Dixon, F. E.: Weather in Old Dublin, Dublin Hist. Rec., 13, 94-107, 1953.

Dixon, H., Lawler, D. M., and Shamseldin, A. Y.: Streamflow trends in western Britain, Geophys. Res. Lett., 33, L1940, doi:10.1029/2006GL027325, 2006.

Dunvan, P.: Ancient and Modern History of Lewes and Brighthelmston: In which are compressed the most interesting events of the county at large, under the Regnian, Roman, Saxon and Norman Settlements, W. Lee, London, 1795.

Edwards, W. and Trotter, F. M.: British Regional Geology: The Pennines and adjacent areas, 3rd Edn., Institute of Geological Sciences (NERC), London, 1954.

Elleder, L., Herget, J., Roggenkamp, T., and Nießen, A.: Historic floods in the city of Prague - a reconstruction of peak discharges for 1481-1825 based on documentary sources, Hydrol. Res., 44, 202-214, 2013.

Enfield, D. B., Mestas-Nunez, A. M., and Trimble, P. J.: The Atlantic Multidecadal Oscillation and its relationship to rainfall and river flows in the continental U.S., Geophys. Res. Lett., 28, 2077-2080, 2001.

Environment Agency: Carlisle Flood Investigation Report, Carlisle, UK, p. 52, 2016.

Esper, J., Frank, D. C., Timonen, M., Zorita, E., Wilson, R. J. S., Luterbacher, J., Holzkämper, S., Fischer, N., Wagner, S., Nievergelt, D., Verstege, A., and Büntgen, U.: Orbital forcing of treering data, Nat. Clim. Change, 2, 862-866, 2012.

Exeter and Plymouth Gazette: 19 January 1866, Supplement title: Great Flood, The British Library Board, London, p. 9, 1866.

Folland, C. K., Knight, J., Linderholm, H. W., Fereday, D., Ineson, S., and Hurrell, J. W.: The Summer North Atlantic Oscillation: Past, Present, and Future, J. Climate, 22, 1082-1103, 2009.

Foulds, S. A., Griffiths, H. M., Macklin, M. G., and Brewer, P. A.: Geomorphological records of extreme floods and their relationship to decadal-scale climate change, Geomorphology, 216, 193207, 2014.

Galloway, J. A.: Storm flooding, coastal defence and the land use around the Thames estuary and tidal river c. 1250-1450, J. Med. Hist., 35, 171-188, 2009.

Garret, W.: An Account of the Great Floods in the Rivers Tyne, Tees, Wear, Eden, c. in 1771 and 1815, E. Charnley, Newcastle, 1818.
Glaser, R., Riemann, D., Schönbein, J., Barriendos, M., Brázdil, R., Bertolin, C., Camuffo, D., Deutsch, M., Dobrovolný, P., van Engelen, A., Enzi, S., Halíčková, M., Koenig, S. J., Kotyza, O., Limanówka, D., Macková, J., Sghedoni, M., Martin, B., and Himmelsbach, I.: The variability of European floods since AD 1500, Climatic Change, 101, 235-256, 2010.

Gray, S. T., Graumlich, L. J., Betancourt, J. L., and Pederson, G. T.: A tree-ring based reconstruction of the Atlantic Multidecadal Oscillation since 1567 A.D., Geophys. Res. Lett., 31, L12205, doi:10.1029/2004GL019932, 2004.

Green, V.: City and suburbs of Worcester, Hulmer and Co., London, 1796.

Griffiths, P. P.: The Two Extremes (Floods and Droughts) Thames Conservancy, 1969.

Gurnell, A., Downward, S., and Jones, R.: Channel planform change on the River Dee meanders, 1876-1992, Regul. River, 9, 187-204, 1994.

Hall, J., Arheimer, B., Borga, M., Brázdil, R., Claps, P., Kiss, A., Kjeldsen, T. R., Kriauciuniene, J., Kriaučiūnienė, Z. W., Lang, M., Llasat, M. C., Macdonald, N., McIntyre, N., Mediero, L., Merz, B., Merz, R., Molnar, P., Montanari, A., Neuhold, C., Parajka, J., Perdigão, R. A. P., Plavcová, L., Rogger, M., Salinas, J. L., Sauquet, E., Schär, C., Szolgay, J., Viglione, A., and Blöschl, G.: Understanding flood regime changes in Europe: a state-of-the-art assessment, Hydrol. Earth Syst. Sci., 18, 27352772, doi:10.5194/hess-18-2735-2014, 2014.

Hains, B. A. and Horton, A.: British Regional Geology - Central England, British Regional Geology Series, Nottingham, 1969.

Hannaford, J. and Marsh, T. J.: High-flow and flood trends in a network of undisturbed catchment in the UK, Int. J. Hydrol., 28, 1325-1338, 2008.

Harrison, J.: Central and Southern Scotland, in: Regional climates of the British Isles, edited by: Wheeler, D. and Mayes, J., Routledge, London, 1997.

Herbert N. M. (Ed.): Gloucester: Quay and docks', in: Vol. 4, A History of the County of Gloucester, the City of Gloucester, Victoria County History, London, 251-258, 1988.

Herget, J. and Meur, H.: Reconstructing peak discharges for historic flood levels in the city of Cologne, Germany, Global Planet. Change, 70, 108-116, 2010.

Historic England: Chester Weir and Salmon Leap, LEN: 1375691, https://www.historicengland.org.uk/listing/the-list/list-entry/ 1375691, last access: 20 October 2015.

Hondius, A.: The Frozen Thames, Museum of London, London, 1677.

Hoskins, W. G.: Two thousand years in Exeter, James Townsend and Sons Ltd, Exeter, 1960.

IH - Institute of Hydrology: The Flood Estimation Handbook, Centre for Ecology and Hydrology, Wallingford, UK, 1999.

Izacke, R.: Antiquities of the City of Exeter, Richard Marriott, London, 1676.

Jervoise, E.: The ancient bridges of the North of England, Architectural Press, London, p. 146, 1931.

Jones, P.: Historical climatology - a state of the art review, Weather, 63, 181-186, 2008.

Jones, P., Conway, D., and Brifffa, K.: Precipitation variability and drought, in: 1997 Climates of the British Isles: Past, present and future, edited by: Hulme, M. and Barrow, E., Routledge, London, 1997. 
Kings, J. and Giles, B.: The Midlands, in: Regional Climates of the British Isles, edited by: Wheeler, D. and Mayes, J., Routledge, London, 1997.

Kjeldsen, T. R., Macdonald, N., Lang, M., Mediero, L., Albuquerque, T., Bogdanowicz, E., Brazdil, R., Castellarin, A., David, V., Fleig, A., Gül, G. O., Kriauciuniene, J., Kohnova, S., Merz, B., Nicholson, O., Roald, L. A., Salinas, J. L., Sarauskiene, D., Sraj, M., Strupczewski, W., Szolgay, J., Toumazis, A., Vanneuville, W., Veijalainen, N., and Wilson, D.: Documentary evidence of past floods in Europe and their utility in flood frequency estimation, J. Hydrol., 517, 963-973, 2014.

Laffan, G. B.: Twickenham, Manor Road, in: Monthly Meteorological Magazine December 1894, edited by: Symons, G. R., Edward Stanford, London, 163-166, 1895.

Lamb, H. H.: Climate history and the modern world, 2nd Edn.,Routledge, London, 1995.

Lambet, A.: Regulation of the River Dee, Regul. River, 2, 293-308, 1988.

Lean, J.: Evolution of the Sun's Spectral Irradiance since the Maunder Minimum, Geophys. Res. Lett., 27, 2425-2428, 2000.

Lewin, J.: Medieval environmental impacts and feedbacks: The lowland floodplains of England and Wales, Geoarchaeology, 25, 267-311, doi:10.1002/gea.20308, 2010.

Llasat, M. C., Barriendos, M., Barrera, A., and Rigo, T.: Floods in Catalonia (NE Spain) since the 14th century. Climatological and meteorological aspects from historical documentary sources and old instrumental records, J. Hydrol., 313, 32-47, 2005.

Longfield, S. A. and Macklin, M. G.: The influence of recent environmental change on flooding and sediment fluxes in the Yorkshire Ouse basin, Hydrol. Process., 13, 1051-1066, 1999.

Luterbacher, J., Xoplaki, E., Dietrich, D., Jones, P. D., Davies, T. D., Portis, D., Gonzalez-Rouco, J. F., von Storch, H., Gyalistras, D., Casty, C., and Wanner, H.: Extending North Atlantic Oscillation Reconstructions back to 1500, Atmos. Sci. Lett., 2, 114-124, 2002.

Macdonald, N.: The application of historical flood information in reassessing flood frequency in Britain, unpublished $\mathrm{PhD}$ thesis, University of Dundee, Dundee, UK, 2004.

Macdonald, N.: An underutilized resource: historical flood chronologies a valuable resource in determining periods of hydro-geomorphic change, edited by: Rowan, J. S., Duck, R. W., and Werritty, A., IAHS/ICCE International Symposium on Sediment Dynamics and the Hydromorphology of Fluvial Systems IAHS Red Book, IAHS Publ., 306, 120-127, 2006.

Macdonald, N.: Epigraphic records: a valuable resource in reassessing flood risk and long-term climate variability, Environ. Hist., 12, 136-140, 2007.

Macdonald, N.: Trends in flood seasonality of the River Ouse (northern England), from archive and instrumental sources since AD 1600, Climatic Change, 110, 901-923, 2012.

Macdonald, N.: Reassessing flood frequency for the River Trent, Central England, since AD 1320, Hydrol. Res., 44, 215-233, 2013.

Macdonald, N. and Black, A. R.: Reassessment of flood frequency using historical information for the River Ouse at York, UK, Hydrolog. Sci. J., 55, 1152-1162, 2010.

Macdonald, N., Werritty, A., Black, A. R., and McEwen, L. J.: Historical and pooled flood frequency analysis for the River Tay at Perth, Scotland, Area, 38, 34-46, 2006.
Macdonald, N., Phillips, I. D., and Bale, G.: Spatial and temporal variability of flood seasonality in Wales, Hydrol. Process., 24, 1806-1820, 2010a.

Macdonald, N., Jones, C. A., Davies, S., and Charnell-White, C.: Developing a historical climatology of Wales from English and Welsh language sources, Weather, 65, 72-81, 2010b.

Macdonald, N., Kjeldsen, T. R., Prosdocimi, I., and Sangster, H.: Reassessing flood frequency for the Sussex Ouse, Lewes: the inclusion of historical flood information since AD 1650, Nat. Hazards Earth Syst. Sci., 14, 2817-2828, doi:10.5194/nhess-142817-2014, 2014.

Macklin, M. G. and Rumsby, B. T.: Changing climate and extreme floods in the British uplands, Trans. Inst. British Geogr., 32, 168186, 2007.

Marsh, T. J. and Hannaford, J.: UK Hydrometric register, Centre for Ecology and Hydrology, Wallingford, Oxon, 2008.

Marsh, T. J. and Harvey, C. L.: The Thames flood series: a lack of trend in flood magnitude and a decline in maximum levels, Hydrol. Res., 43, 203-214, 2012.

Marsh, T. J. and Lees, M. L.: Hydrological data UK: Hydrometric register and statistics 1996-2000, Centre for Ecology and Hydrology, Wallingford, Oxon, 2003.

Marsh, T. J., Greenfield, B. J., and Hannaford, J.: The 1894 Thames flood - a reappraisal, Proc. Inst. Civ. Eng.: Water Manage., 158, 103-110, 2005.

McEwen, L. J.: Sources for establishing a historic flood chronology (Pre 1940) within Scottish River Catchment, Scott. Geogr. Mag., 103, 132-140, 1987.

McEwen, L. J.: Extreme rainfall and its implications for flood frequency: A case study of the Middle River Tweed Basin, Scotland, Trans. Inst. British Geogr., 147, 287-298, 1989.

McEwen, L. J.: The establishment of a historical flood chronology for the River Tweed catchment, Berwickshire, Scotland, Scott. Geogr. Mag., 106, 37-47, 1990.

McEwen, L. J. and Werritty, A.: 'The Muckle Spate of 1829': the physical and societal impact of a catastrophic flood on the River Findhorn, Scottish Highlands, Trans. Inst. British Geogr., 32, 6689, 2007.

Meteorological Office: UK Annual Rainfall web-site, http://www.met-office.gov.uk/climate/uk/averages/images/ RainAnnual6190.gif, last access: 2002.

Morgan, W.: Morgan's Map of the Whole of London in 1682, British History, http://www.british-history.ac.uk/no-series/ london-map-morgan/1682/map (last access: 6 June 2016), 1682.

Mudelsee, M., Börngern, M., Tetzlaff, G., and Grünewald, U.: No upward trends in the occurrence of extreme floods in central Europe, Nature, 425, 166-170, 2003.

Muscheler, R., Joos, F., Beer, J., Müller, S. A., Vonmoos, M., and Snowball, I.: Solar activity during the last $1000 \mathrm{yr}$ inferred from radionuclide records, Quaternary Sci. Rev., 26, 82-97, 2007.

NERC: Flood Studies Report, Institute of Hydrology, Wallingford, 1975.

Newson, M. D.: Flooding and flood hazard in the United Kingdom, Oxford University Press, Oxford, p. 59, 1975.

NRA: The Dee Regulation Scheme, National River Authority, Cardiff, p. 4, 1993.

O'Connell, P. E., Beven, K. J., Carney, J. N., Clements, R. O., Ewen, J., Fowler, H., Harris, G. L., Hollis, J., Morris, J., O’Donnell, G. M., Packman, J. C., Parkin, A., Quinn, P. F., Rose, S. C., Shep- 
herd, M., and Tellier, S.: Review of impacts of rural land use and management on flood generation Impact study report R\&D Technical Report FD2114/TR 2004, Joint Defra/EA Flood and Coastal Erosion Risk Management R\&D Programme, London, p. $142,2004$.

Oppenheimer, C.: Climatic, environmental and human consequences of the largest known historic eruption; Tambora volcano (Indonesia) 1815, Prog. Phys. Geogr., 27, 230-259, 2003.

Ordnance Survey: County Series 1:25000 Sussex, 1st Edn., HMSO, London, 1875.

Parent, E. and Bernier, J.: Bayesian POT modelling for historical data, J. Hydrol., 274, 95-108, 2003.

Parry, S., Barker, L., Prosdocimi, I., Lewis, M., Hannaford, J., and Clemas, S.: Hydrological summary for the United Kingdom: December 2015, NERC/Centre for Ecology and Hydrology, Wallingford, UK, 12 pp., 2016.

Patterson, I. and Lane, S.: The relationship between Lamb weather types and long-term changes in flood frequency, River Eden, UK, Int. J. Climatol., 32, 1971-1989, 2012.

Payne, P. L.: The Hydro, Aberdeen University Press, Aberdeen, 1988.

Payrastre, O., Gaume, E., and Andrieu, H.: Usefulness of historical information for flood frequency analyses: developments based on a case study, Water Resour. Res., 47, W08511, doi:10.1029/2010WR009812, 2011.

Pearce, J.: Hydrologist experiences in times of flood: Sussex 2000, BHS 8th National Hydrology 2000, Symposium, 6-8 September 2000, Birmingham, 2002.

Popper, W.: The Cairo Nilometer, The University of California Press, Berkley, p. 269, 1951.

Rocque, J.: Map of London, Pine \& Tinney, London, 1746.

Rocque, J.: A plan of the City of York, in: Scarborough, York and Leeds: The town plans of John Cossins 1697-1743, edited by: Murray, H., Yorkshire Architectural and York Archaeological Society Ebor Press, York, p. 53, 1750.

Roy, M. G.: Highland and Islands Scotland, in: 1997 Regional climates of the British Isles, edited by: Wheeler, D. and Mayes, J., Routledge, London, 1997.

Rumsby, B. T. and Macklin, M. G.: Channel and floodplain response to recent climate change: the Tyne basin, northern England, Earth Surf. Proc. Land., 19, 499-515, 1994.

Salzman, L. F.: The borough of Lewes: Introduction and history, in: A History of the County of Sussex: Vol. 7: The rape of Lewes, Victoria County History, London, 7-19, 1940.

Sawyer, J.: Notes on the Ridge family, being some extracts from "A Book of Memorandums Kept by William Ridge”, 1715-1785, Sussex Archaeological Collections, Sussex, p. 119, 1890.

Schillereff, D. N. Chiverrell, R. C., Macdonald, N., and Hooke, J. M.: Flood stratigraphies in lake sediments: a review, Earth Sci. Rev., 135, 17-37, 2014.

Sheffer, N. A., Rico, M., Enzel, Y., Benito, G., and Grodek, T.: The palaeoflood record of the Gardon river, France: a comparison with the extreme 2002 flood event, Geomorphology, 98, 71-83, 2008.

Sir Lauder, T. D.: An account of the great floods of August 1829, in the province of Moray and the adjoining districts, 3rd Edn., reprint 1873, J. M. Gillivray \& Sons, Elgin, Scotland, 1830.
Sir Maxwell, H.: The Chronicle of Lanercost, 1272-1346 (translated with notes), J. Maclehose, Glasgow, p. 416, 1913.

Smith, K. and Tobin, G.: Human Adjustment of the flood hazard, Longman, London, 1979.

Star: 23 February, Issue 2032, London, England, 1795.

Star: 26 October, Issue 2868, London, England, 1797.

Starkel, L.: Change in the frequency of extreme events as the indicator of climatic change in the Holocene (in fluvial systems), Quartern. Int., 91, 25-32, 2002.

Stewart Brown, R.: The Old Dee Bridge at Chester, J. Chester Archaeol. Soc., NS30, 64-65, 1933.

St James Chronicle: 14-17 February, Issue 5769, London, England, 1795.

Symons, G. J. and Chatterton, M. A.: The November floods of 1894 in the Thames valley, Q. J. Roy. Meteorol. Soc., 12, 189-208, 1895.

Symons, G. R.: British Rainfall 1890, G. Shield, London, p. 5, 1891.

Todd, B., Macdonald, N., and Chiverrell, R. C.: Revision and extension of the composite Carlisle rainfall record, NW England: 1757-2012, Int. J. Climatol., 35, 3593-3607, 2015.

Trouet, V., Esper, J., Graham, N. N. E., Baker, A., Scourse, J. D., and Frank, D. C.: Persistent Positive North Atlantic Oscillation Mode Dominated the Medieval Climate Anomaly, Science, 324, 78-80, 2009.

Tyrrell, J. G. and Hickey, K. J.: A flood chronology for Cork city and its climatological background, Irish Geogr., 24, 81-90, 1991.

Vaquero, J. M.: Solar Signal in the Number of Floods Recorded for the Tagus River Basin over the Last Millennium, Climatic Change, 66, 23-26, 2004.

Wanner, H., Beer, J., Bütikofer, J., Crowley, T. J., Cubasch, U., Flückiger, J., Goosse, H., Grosjean, M., Joos, F., Kaplan, J. O., Küttel, M., Müller, S. A., Prentice, I. C., Solomina, O., Stocker, T. F., Tarasov, P., Wagner, M., and Widmann, M.: Mid- to Late Holocene climate change: an overview, Quaternary Sci. Rev., 27, 1791-1828, 2008.

Webb, B. W. and Walling, D. E.: Longtern variability in the thermal impact of river impoundment and regulation, Appl. Geogr., 16, 211-223, 1996.

Werritty, A., Paine, J., Macdonald, N., Rowan, J. S., and McEwen, L. J.: Use of proxy flood records to improve estimates of flood risk: lower River Tay, Scotland, Catena, 66, 107-119, 2006.

Wetter, O., Pfister, C., Weingartner, R., Luterbacher, J., Reist, T., and Trösch, J.: The largest floods in the High Rhine basin since 1268 assessed from documentary and instrumental evidence, Hydrolog. Sci. J., 56, 733-758, 2011.

Wheater, H. and Evans, E.: Land use, water management and future flood risk, Land Use Policy, 26, S251-S264, 2009.

Williams, A. and Archer, D.: The use of historical flood information in the English Midlands to improve risk assessment, Hydrolog. Sci. J., 47, 67-76, 2002.

Williams, A. and Martin, G.: Domesday book: a complete translation, Penguin, London, p. 1436, 2003.

Williams, K.: Read All About It!: A History of the British Newspaper, Routledge, Abingdon, UK, p. 422, 2009.

Woodcock, A.: The archaeological implications of coastal change in Sussex, in: The Archaeology of Sussex to AD2000, edited by: Rudling, D., Heritage, University of Sussex, Sussex, 1-16, 2003. 